\title{
Sahîh-i Buhârî Nüshalarına Dair Yeni Bulgular: Bulak Baskısı, Yûnînî Yazmaları ve Abdullah b. Sâlim el-Basrî Nüshası *
}

\author{
Arafat Aydın** - Ali Albayrak***
}

\begin{abstract}
Some New Findings on Manuscript Copies of Sahīh al-Buhkārī: The Bulak Printing, the Yūnīnī Manuscripts and the Ditto of Abdullah b. Sālim al-Basrī

It is unclear whether the manuscript sent from Istanbul to Egypt to be used for the Bulak printing of Sahīh al-Bukhārī, made on the order of Sultan Abdülhamid II, is the main Yūninī (d. 701/1302) copy. Nor is it clear what happened to the manuscript after the printing or what other copies were used. These uncertainties are due to the scarcity of works on Yūnīni and the insufficiency of sources. In this paper we have tried to eliminate some of these uncertainties by using the rich collection of manuscripts in Turkey. It has been determined that the original copy of Yuninini does not exist in Turkey and that the Bulak printing made by scholars of al-Azhar was based on the copy of Abdullah b. Sālim al-Basrī (d. 1134/1722), the most eminent copy of Yunini manuscript, as well as those of Muhammed al-Mizzī, Bedrānī and Taqī al-dīn al-Subkī and that of Muhammed b. Ilyas, revised by Hāfiz Yusuf al-Mizzì. We have provided information about the copies by Abdullah b. Sālim and other Yūninī manuscripts found in Turkey. To show that there were similar efforts both before and after Yūnīnī, we have also mentioned the copy of Sagānī, which was praised by Ibn Hajar al-Askalānī, as well as the gloss by Sehārenfūrì who made the first print of Sahìh al-Bukhārī in the Muslim world. It is hoped that the copies and the information presented in this paper will lead to some further works on the topic.
\end{abstract}

Key words: Bukhārī, al-Jāmi‘ al-Sahīh, Yūnīnī, Abdullah b. Sālim al-Basrī, Sultan Abdülhamid II, Bulak.

* Bu araştırma kapsamında Topkapı Sarayı Müzesi ve Süleymaniye kütüphaneleri başta olmak üzere İstanbul ve Anadolu'daki diğer yazma eser kütüphaneleri de dahil Türkiye'de mevcut bulunan yaklaşık 150o'ün üzerindeki Sahîh-i Buhârî yazması incelemeye tâbi tutulmuştur. Yûnînî nüshası hakkındaki değerlendirmeler bu makalede, kalan diğer tetkik ve değerlendirmeler ise muhtelif çalışmalarımızda paylaşılacaktır.

** Yazma Eser Uzmanı, Türkiye Yazma Eserler Kurumu Başkanlığı (arafataydin@yek.gov.tr).

${ }^{* * *}$ Araştırmac1. 


\section{Giriş}

Buhârînin (ö. 256/870) el-Câmiu’s-sahîh'i, gerek yazma nüshalarının yoğun olarak kullanıldığı dönemlerde gerekse matbu hale geldiği son 150 yılı kapsayan dönemde, nüshaları ve farklı rivayetleri üzerine yapılan çalışmalar itibariyle diğer İslâmî literatüre nasip olmayacak ölçüde ilgiye mazhar olmuştur.

el-Câmiu's-sahîh'in yazma nüshalarının günümüze intikal sürecinde eserin farklı rivayetlerini bir araya getirme ve aralarındaki farkların tamamına işaret etme faaliyetini kusursuza yakın bir şekilde icra eden Şerefüddîn el-Yûnînî (ö. 701/1302) özellikle dikkat çekmektedir. Gösterdiği ilmî titizlik ve gayret sayesinde Yûnînînin bu çalışması Sahîh-i Buhârînnin temel müracaat metni olmuş ve bu nüsha Sultan II. Abdülhamid'in emriyle basılmıştır. Bu baskının Ezher ulemâsından oluşan on altı kişilik bir heyet tarafından, o dönemde musahhihlerinin ilmî ehliyetiyle dikkatleri çeken Bulak Emîriyye Matbaası'nda yapılmış olması ise hem bahsi geçen ihtimamın en büyük göstergelerinden biri olmuş hem de Yûnînînin gayretinin büyük bir takdiri niteliğini kazanmıştır. Eserin basımının ilmî sorumluluğunu üstlenen Ezher ulemâsının, Yûnînînin hangi yazma nüshalarını esas alarak eseri yayımladıklarına dair herhangi bir beyanda bulunmamış olmaları, böylesi bir neşirde olmaması gereken birtakım muğlaklıkları beraberinde getirmiştir. Ezherliler'in hangi yazmadan ne oranda istifade ettikleri ve eserin yayınında nasıl bir emek sarfettikleri meselesi bir yana, konunun asıl sorgulanan ve merak uyandiran yönü, Sultan Abdülhamid tarafından İstanbul'dan Mısır'a gönderilen yazma nüshanın Yûnînînin asıl nüshası olup olmadığı ve bu mühim nüshanın basıldıktan sonraki âkıbetidir.

Bulak baskısında metnin hâşiyesinde Yûnînînin rumuzlarla ifade ettiği nüsha farklarına dair açıklamaların yanında eser boyunca her iki-üç sayfada bir sıklıkla görülebilen "Yûnînînin asıl nüshasında burası şöyledir, fer' nüshasında şöyledir” tarzındaki açıklamaların mevcudiyeti dikkate alındığında, basım esnasında hem asıl nüshanın hem de bu asıldan istinsah edilmiş kopya nüshaların dikkate alındığı ve bu karşılaştırmaların Ezherli âlimler tarafından yapıldığ 1 izlenimi edinilmektedir. Nitekim konuyla ilgili genel kanaat, İstanbul'dan gönderilen ve baskıya esas kabul edilen nüshanın Yûnînînin asıl nüshası olduğu yönündedir. Eserin girişinde heyet adına açıklamada bulunan Ezher şeyhi Hasûne en-Nevâvînin (ö. 1924), kendilerine "Yûnînî nüshasının gönderildiğini”" ifade etmesi de bu yöndeki kanaati pekiştirmiştir.

1 “Âsitâne-i Aliyye'deki Mülûkiyye Kütüphanesi’nde (el-Hizânetü’l-mülûkiyye) mahfuz Yûnînî nüshası” tabirini kullanmaktadır. Bk. Buhârî, el-Câmiu's-sahîh (Bulak), Hasûne en-Nevâvînin mukaddimesi, s. 2. 
Konu bu yönüyle birtakım araştırmacıların ilgisini çekmiş ve Mısır'dan Ahmed Muhammed Şâkir ${ }^{2}$ (ö. 1958), Fas'tan Muhammed el-Menûnî̉ (ö. 1999) ve Türkiye'den Fuat Sezgin ${ }^{4}$ Yûnînî nüshası ve Bulak (Sultâniye) baskısına dair açıklamalarda bulunmuşlardır. Son dönemde Buhârî nüshalarına dair en ayrıntılı çalışmayı yapan Cum'a Fethî Abdülhalîm ${ }^{5}$ de zikredilmesi gereken önemli bir isimdir. Bu araştırmalar içerisinde Ahmed Şâkir, Yûnînînin aslının kullanılıp kullanılmadığı meselesini ayrıntılı bir şekilde sorgulamış ve "kesin bir karara varabilmek için basımda kullanılan asla bakmak gerektiğini”’ ${ }^{\prime \prime}$ vurgulamıştır.

Temel hadis kaynaklarının yazma nüshaları üzerine yoğunlaşan ilmî çalışmalarımız çerçevesinde karşılaştığımız bazı Buhârî yazmalarında Yûnînînin rumuz ve açıklamalarına ilâve olarak sadece Bulak baskısında yer alan ve Ezher ulemâsı tarafından Yûnînînin aslı ile kopyaları arasında karşılaştırmalar yapıldığını hissettiren, mezkûr açıklamaların aynı lafızlarla bu yazmalarda da mevcut olması dikkatimizi çekmiştir. Matbu nüshadaki bu tarz açıklamalarla yazma nüshalardaki açıklamaları birbiriyle karşılaştırdığımızda bu ibarelerin tamamına yakınının bu yazmalardan alındığını tespit ettik. Devam eden araştırmalarımız neticesinde karşılaştığımız yazmaların Abdullah b. Sâlim el-Basrî (ö. 1134/1722) nüshası olduğu ve bu ilâve bilgilerin bizzat Abdullah b. Sâlim tarafından kendi nüshasının kenarına not edildiği kesinleşmiştir. Diğer yandan İstanbul'dan gönderilen nüshanın Osmanlı arşiv vesikalarında "nüsha-i asliyyenin esah rivayeti” ${ }^{7}$ şeklinde tasvir edilmiş olması başta olmak

2 Buhârînin Bulak baskısının Dârü'l-cîl tarafından yeniden yapılan ofset baskısına, yayınevi tarafından "en-Nüshatü'l-Yûnîniyye min Sahîhi'l-Buhârî” başlı̆̆ıyla mukaddime olarak konulan çalışmasında Ahmed Şâkir, kısa da olsa ilk sayılabilecek bir değerlendirme yapmıştır. Ancak -ileride değineceğimiz üzere- yüzeysel bir bilgiyle tanıttığı bir Yûnînî kopyasının gerçekte ne olduğunu farkedebilseydi, burada belirteceğimiz yeni bulguların bir kısmı daha o zamandan yazılmış olurdu.

Menûnî, “Sahîhu'l-Buhârî fi'd-dirâsâti'l-magribiyye” s. 500-49. Yazma eserleri kullanarak ve Bulak baskısındaki hâmişleri satır satır inceleyerek ilk ve belki de en doğru bilgileri vermekle öne çıkan Menûnî, bu makalemizde istifade ettiğimiz en önemli isimdir.

Sezgin, Buhârînin Kaynakları Hakkında Araştırmalar. Çalışmasının asıl konusu Buhârînin yazılı kaynakları olmasına rağmen Yûnînî nüshasına da ayrıntılı bir şekilde değinen Fuat Sezgin, yazma eserleri kullanma açısından takdire şayan bir tutum sergilemiş ve araştırmanın yapıldığı yılların imkânlarına rağmen sahaya önemli bir derinlik kazandırmıştır.

Abdülhalîm, Rivâyâtü̉l-Câmii’s-sahîh. İki cilt halinde yayımlanmış olan bu çalışma, Yûnînînin er-Rumûz/el-Usûl olarak bilinen ve nüshasını doğru tanımak için elzem olan risâlesini içermesi bakımından da önem arzetmektedir.

6 Şâkir, s. 11.

7 Başbakanlık Osmanlı Arşivi, Y. PRK. MK. 6/89 (Altuntaş, “Osmanlı İlim Geleneğinde Buhârîhânlık", s. 22'den naklen). 
üzere, bunu teyit eder mahiyette, Bulak baskısının mukaddimesinde tashihe esas kabul edilen nüshanın "çok net ve gayet sahih bir Yûnînî kopyası"8 olarak tanıtılması da dikkate alındığında bu baskıda kullanılan temel nüshanın Yûnînînnin aslı olmadığını, onun en sahih kopyası olarak kabul edilen ${ }^{9} \mathrm{Ab}$ dullah b. Sâlim nüshası olduğunu artık kesin bir dille ifade etmemiz mümkün olmaktadır.

Bu çalışmada Abdullah b. Sâlim nüshası ve ondan istinsah edilen nüshalar ayrıntılı olarak incelenmeden önce, Buhârînnin erken dönem nüshaları ve Yûnînînnin bunlar üzerinde tam olarak ne yaptığı konusu özetle ele alınacak ve İslâm âleminde pek bilinmeyen Yûnînî benzeri çalışmalar tanıtılacaktır. Ardından Yûnînî kopyaları ve Bulak baskısıyla ilgili ayrıntılara değinilecektir.

Ağılıklı olarak Türkiye’deki yazma eserlerin kullanılacağı bu çalışma, Türkiye kütüphanelerindeki zengin yazma eser birikimini bir nebze de olsa yansitacak mahiyettedir.

\section{Buhârî Nüshaları}

Kendisinden önce yazılmış olan hadislerin sadece sahih olanlarıyla kitabını yazan Buhârî, kendisinden sonraki hadis edebiyatını șekillendirecek kadar haklı bir şöhrete kavuşmuştur. Onun Sahîh'i daha çok iki râvisi aracılığıyla sonraki nesillere ulaştırılmıştır. Bunlardan Muhammed b. Yûsuf el-Firebrî (ö. 320/932) çok meşhur olmuş ve rivayeti çeşitli nüshalar şeklinde günümüze ulaşmıştır. Buhârî̉nin diğer önemli râvisi İbrâhim b. Ma'kıl en-Nesefî (ö. 293/908) rivayeti ise nüsha şeklinde olmasa da içerik olarak şerhlerde nakledilmiştir.

Firebrî̀den Sahîh'i dinleyen ve kendileri için nüsha oluşturan en meşhur râviler Ebû Ali İbnü's-Seken (ö. 353/964), Ebû Zeyd el-Mervezî (ö. 371/981), Ebû İshak el-Müstemlî (ö. 376/986), İbn Hammûye es-Serahsî (ö. 381/991), Ebü’l-Heysem el-Küşmîhenî (ö. 389/998), Ebû Ahmed el-Cürcânî (ö. 373/983) ve İbn Şebbûye'dir (ö. 376/986). Kaynaklarda ayrıca Nưaymî (ö. 386/996), Ahsîketî (ö. 346/957) ve Kûş̧ânînin ${ }^{10}$ (ö. 391/1001) isimleri de

8 نسخة شديدة الضبط بالغة الصحة من فروع النسخة اليونينية. Bk. Buhârî el-Câmiu’s-sahîh (Bulak), Mukaddime, s. 3.

9 Kettânî, Fihrisüll-fehâris, I, 198.

10 Diğer ikisi gibi günümüze ulaşmadığı düşünülen Kûşânî rivayetinin İbnü'l-İmâd elKureşî tarafından 743’te yazılmış bir kopyası (Süleymaniye Ktp., Ayasofya, nr. 773) ile Muhammed b. Rıdvân el-Mevsılî tarafından 749'da yazılmış başka bir kopyası (Süleymaniye Ktp., Turhan Vâlide Sultan, nr. 67) mevcuttur. Fakat sihhat dereceleri ve ilmî değerleri tartışmaya açıktır. 
zikredilmekte olup bunlardan Nuaymî nüshası bir dönem kullanıldıktan sonra unutulmuştur.

Firebrî ile Nesefî arasında ve Firebrînnin yukarıda belirtilen râvileri arasında bazı nüsha farklılıkları olduğundan bunları yansıtan çalışmalar çok erken dönemde başlamış̧ır. Küşmîhenînin meşhur talebesi Kerîme elMerveziyye (ö. 465/1073) nüshası ile Serahsînin rivayetini nakleden ve zamanla Buhârînin en meşhur rivayeti olan Ebü’l-Vakt (ö. 553/1158) nüshası müstakil olarak devam etmiş olsa da birden fazla rivayeti içeren nüshalar daha çok kabul görmüştür. Bunlardan Müstemlî, Serahsî ve Küşmîhenî rivayetlerini bir nüshada yansıtan Ebû Zer (ö. 434/1043) ile Mervezî ve Cürcânî rivayetlerini nakleden Asîlî (ö. 392/1002) nüshaları önemli çalışmalar olarak bilinmektedir.

\section{Nüsha Farklarına Dair Çalışmalar}

Farklı nüshaları tek nüsha halinde yansıtan çalışmalar sonraki dönemlerde de devam etmiştir. Bunların içerisinde en önemliler olarak gördüğümüz üç nüsha mevcuttur. Bunlardan ilki Sagānî (ö. 650/1252) nüshası, en meşhuru ise Yûnînî (ö. 701/1302) nüshasıdır. XIX. yüzyılda yaşayan ve Buhârî nüshalarıyla ilgili en ayrıntılı çalışmayı yapan Sehârenpûrî ise (ö. 1297/1880) bu tür bir çalışmayı yapan belki de en son kişidir.

Asıl konumuz olan Yûnînîye ayrıntılı olarak değinmeden önce İslâm dünyasında pek tanınmayan diğer iki çalışmadan kısaca bahsetmek yerinde olacaktır.

\subsection{Sagānî Nüshası}

Dil konusunda otorite kabul edilen Lahorlu (Pakistan) Radıyyüddin Hasan b. Muhammed es-Sagānî (577-650) aynı zamanda fikıh ve hadis âlimidir. Daha çok Meşâriku'l-envâr ve el-Mevzûât adlı eserleriyle tanınan Sagānînin Buhârî nüshası, İbn Hacer'in çok önem verdiği ve farklılıklarına muhakkak değindiği bir çalışmadır. ${ }^{11}$

Sagānî bu çalışmasında İbnüll-Husrî (536-616) ve diğerlerinden dinlediği Ebü’l-Vakt nüshası ile Ebû Zer nüshası arasındaki farkları göstermekte, bunun yanında "Bağdat nüshası" olarak bilinen ve üzerinde Firebrînin tashih

11 İbn Hacer'in Sagānîden yaptığı bu nakillerin bir kısmı üzerine kaleme alınmış bir makale için bk. Sellûm, "Nüshatü'l-İmâm es-Sagānî min Sahîhi’l-Buhârî”, s. 8-16. 
kaydı bulunan bir nüshanın da farklarını belirtmektedir. ${ }^{12}$ Fakat onun bir nüshayı esas alıp diğer nüshaların farkını gösterme şeklinde bir çalışma mı yaptığı, yoksa o dönemde pek görülmeyen bir şekilde nüshalar arasında kimi zaman bir tercihte mi bulunduğu net değildir. Başında zikretmiş olduğu EbülVakt senedinin tamamen sembolik olup Bağdat nüshasını ana metin yaparak Ebû Zer nüshasının farklarını yansıtmış olması da mümkündür.

Çok önemli olmasına rağmen pek bilinmeyen Sagānî nüshasının Türkiye'de kopyaları mevcuttur. ${ }^{13}$ Hindistan'da Şeyh Ebü'l-Hasan en-Nedvî Merkezi’nde de bir nüshasının olduğu ifade edilmiştir. ${ }^{14}$ Sagānî nüshasının meşhur olmamasında bize göre asıl etken Yûnînî nüshasının tanınmasında etkisi olan Kastallânî (ö. 923/1517) ve Abdullah b. Sâlim (ö. 1134/1722) gibi bu nüshayı meşhur edecek isimlerin çıkmamış olmasıdır.

\subsection{Sehârenpûrî Hâşiyesi}

Hindistanlı Ahmed Ali es-Sehârenpûrî (ö. 1297/1880), İslâm dünyasında Buhârî̉nin el-Câmiu's-sahîh'inin basımını yapan (1270/1853) ilk kişidir. Sehârenpûrî bu baskıda elindeki Yûnînî nüshasını temel almıştır. Bu nüsha Sehârenpûrînin hocası Muhammed İshak’n rivayetidir ki Şah Veliyyullah ed-Dihlevînin de (ö. 1176/1763) içinde bulunduğu bir senetle Abdullah b. Sâlim el-Basrî̀ye, yani ileride bahsedeceğimiz, Yûnînînnin en sağlam kabul edilen kopyasına dayanmaktadır. ${ }^{15}$

Sehârenpûrînnin bu baskıya yazdığı hâşiye, yukarıda bahsettiğimiz Sagānî nüshası ile Yûnînî nüshasını içerdiği gibi, ancak şerhlerde ulaşabileceğimiz Nesefî nüshasını, ayrıca Firebrînin râvilerinden İbnü’s-Seken ve İbn Şebbûye

12 Sagānî, çalışmasında hangi nüshaları esas aldığını nüshasının sonunda bizzat kendisi ifade etmektedir. Bk. Süleymaniye Ktp., Damad İbrâhim Paşa, nr. 267, vr. $268^{\mathrm{a}}$.

Türkiye kütüphanelerindeki Sagānî nüshaları üzerine yazma eser uzmanlık tezi hazırlanmıştır. Bk. Aydın, "Sagânînin Sahîh-i Buhârî Nüshası ve Türkiye Kütüphanelerindeki Yazmaları".

el-Câmiu's-sahîh bi-hâşsiyetill-muhaddis es-Sehârenfûrî, Takıyyüddin en-Nedvînin mukaddimesi, I, 17.

15 Sehârenpûrî, Mekke'de yaşayan Muhammed İshak'ı 1259 (1843) yılında dinlemiştir. Muhammed İshak, dedesi Abdülazîz ed-Dihlevîden (1159-1239/1824), o da babası Şah Veliyyullah ed-Dihlevîden (ö. 1176/1762) hadis dinlemiştir. Şah Veliyyullah ise hadisi, Abdullah b. Sâlim'in (ö. 1134) talebeleri olan Şeyh Muhammed Efdal es-Siyâlkûtî (ö. 1146), Ebû Tâhir el-Kürdî (ö. 1145) ve Abdullah b. Sâlim’in oğlu Sâlim'den (ö. 116o) almıştır. Bk. el-Câmiu's-sahîh bi-hâşsiyetill-muhaddis es-Sehârenfûrî, Mukaddime, s. 18. Sehârenpûrî hakkında bilgi için bk. Özşenel, Pakistan'da Hadis Çalışmaları, s. 101. 
rivayetlerini de içermektedir. Bu yönüyle çok zengin bir kaynak ve nüsha farklılıklarıyla ilgili en ayrıntılı çalışma olmaktadır. ${ }^{16}$

Sehârenpûrî, çalışmasının ana metnini oluştururken tek nüshaya bağlı kalmamış, nüshalar arası tercihlerde bulunarak en doğru metni bulmaya çalışmıştır. Bu yönüyle onun ana metninde, Yûnînînin ana metninde bulunan bazı hatalar bulunmamaktadır. ${ }^{17}$ Şüphesiz bunda Sagānînin nüshasının ve İbn Hacer'in (ö. 852/1449) değerlendirmelerinin payı büyüktür. Nitekim Sehârenpûrî, bazı hadislerin takdim-tehirinde ve Sahîh'i otuz cüze bölmede de Sagānî nüshasına uymuştur.

Hindistan'da yapılan iki ciltlik baskısı iç içe geçmiş hâşiyeler sebebiyle oldukça karışık ve istifadesi zor bir haldeyken son dönemde yapılan güzel bir tahkikle kenardaki açıklamalar dipnotlar şekline dönüştürülmüş ve eser yeni haliyle on beş cilt halinde basılmıştır. ${ }^{18}$

\section{Yûnînî Nüshası}

Yûnînî ${ }^{19}$ nüshasının bir ana metni, bir de diğer nüshaların farklarına işaret edilen kenarlardaki notlar kısmı vardır. Bunları ayrı ayrı ele almak yerinde olacaktır.

\subsection{Yûnînînin Ana Metni}

Yûnînînin nüshasını kendisi gibi Hanbelî mezhebine mensup olan İbn Zeyd $^{20} 669$ yılında kaleme almıştır. ${ }^{21}$ İbn Zeyd'in yazdığ 1 bu ana metin,

16 Bütün bu rivayetlere ayrı ayrı mı ulaştığı yoksa Buhârî şerhlerinden mi naklettiği net değildir. Şerhlere bakılarak yapılan çalışmanın bir örneği olarak, İbn Hacer'in Fethu'lbârî adlı eserinde bulunan nüshalara dair notların nüsha farkları olarak gösterildiği bir el-Câmiu's-sahîh nüshası için bk. Millet Ktp., Feyzullah Efendi, nr. 474. Eserin ikinci/son cildi olmadığından çalışmayı yapan kişinin kaydına ulaşılamamıştır.

17 Yûnînînin ana metninde, dolayısıyla bugünkü Buhârî baskılarında bulunan bu hatalarla ilgili olarak henüz neşredilmemiş bir çalışma bulunmaktadır: Albayrak, Sahîh-i Buhârînin Tashihi.

18 el-Câmiu's-sahîh bi-hâş̧iyeti'l-muhaddis es-Sehârenfûrî. Yukarıda naklettiğimiz bilgiler, kitabı tahkik eden Nedvînin mukaddimesinden alınmıştır.

19 Aslen Ba'lebek (Yûnîn) bölgesinden olup ailesiyle Dımaşk’a yerleşen Muhammed b. Ali el-Yûnînî hakkında ayrıntılı bilgi için bk. Kızıl, "Yûnînî”, s. 595-96.

20 Ebû Abdullah Muhammed b. Abdülmecîd b. Ebü’l-Fazl b. Abdurrahman b. Zeyd için bk. Safedî, A'yânüll-asr, IV, 545.

21 Anlaşılan o ki, nüshası üzerinde gösterdiği hassasiyeti yazı kısmında da gösteren Yûnînî, bu nüshayı yazısının güzelliğiyle tanınan İbn Zeyd’e yazdırmıştır. Bu ve 
Hanbelîliğin Dımaşk'ta yerleşmesinde etkisi olan ve Cemmâilî olarak tanınan Abdulganî el-Makdisînin ${ }^{22}$ (540-600) yazdığ Kerîme nüshasının kopyasıdır ki içerdiği senet şu şekildedir: Küşmîhenî (ö. 389) $\rightarrow$ Kerîme (363-463) $\rightarrow$ Ferrâ (433-519) $\rightarrow$ Ertahî (507-601) $\rightarrow$ Cemmâîlî.

Cemmâillî bu nüshayı Ferrẩnın asliyla ve Kerîme’nin diğer bir talebesi Ebû Sâdık ${ }^{23}$ (ö. 517) nüshasıyla mukabele etmiş ve kendi nüshasında olmayan kısımları kenarlara kırmızıyla yazmıştır. İbn Zeyd’in yazdığı asılda da böyle olduğundan Yûnînî nüshasını aynen yansıtanlarda bu kırmızı yazılar kenarlarda mevcuttur. $^{24}$

Cemmâilînnin bu nüshası Yûnînînin daha çocuk yaşta bulunduğu bir mecliste Zebîdîye ${ }^{25}$ dinletilmiş, böylece onun Ebü'l-Vakt rivayeti de elde edilmiştir: İbn Hammûye es-Serahsî (293-381) $\rightarrow$ Dâvûdî (364-467) $\rightarrow$ Ebüll-Vakt (458-553) $\rightarrow$ Zebîdî (546-631) $\rightarrow$ Yûnînî (621-701).

Yûnînî hem nüshasının kenarlarında hem de rumuzlarını açıkladığı risâlesinde ${ }^{26}$ semâ‘ ettiği aslın (aslü’s-semâ') Hammevî ${ }^{27}$ rivayeti olduğunu özellikle belirtmektedir. Fakat Yûnînî, ana metni Kerîme nüshası iken semâ‘n nasıl Hammevî rivayeti olduğunu izah etmemektedir. Belki de nüsha farklarını

bundan sonraki bilgiler ileride değineceğimiz gibi Yûnînînin Nüveyrî kopyasının sonunda yer almaktadır.

22 el-Kemâl fî esmâirr-ricâl isimli eserin müellifi olan Ebû Muhammed Abdülganî b. Abdülvâhid b. Ali b. Sürûr el-Makdisî el-Cemmâîlî için bk. Mizzî, Tehzîbü’l-Kemâl, I, 38.

23 Ebû Sâdık Mürşî̀ b. Yahyâ el-Medînî için bk. Zehebî, A 'lâmünn-nübelâ', XIV, 545 .

24 Şayet Yûnînî bu kısımları başka nüshalarda da tespit etmişse bunu kırmızı yazıların üstüne rumuzlar koymak suretiyle göstermiş, değilse öylece bırakmıştır. Yani üzerinde hiçbir işaretin bulunmadığı kırmızı yazılar Ebû Sâdık’n Kerîme nüshasını yansıtmaktadır. Ebû Sâdık’n Kerîme rivayeti Türkiye'de mevcuttur (Konya Bölge Yazma Eserler Ktp., nr. 4772).

25 İbnü'z-Zebîdî olarak da bilinen Hüseyin b. Mübârek b. Muhammed b. Yahyâ elBağdâdî ez-Zebîdî için bk. Fâsî, Zeylü't-Takyîd, I, 517.

26 Türkiye'deki birçok Yûnînî yazmasının başında -özellikle de ileride tanıtacağımız Bedrânî nüshalarında- nakledilen bu risâlenin tamamı Cumáa Fethî Abdülhalîm’in çalışmasında yer almıştır. Bk. Abdülhalîm, Rivâyâtüll-Câmiỉs-sahîh, s. 668-77. Ayrıca Rosemarie Quiring-Zoche tarafından yazılan bir makalede Berlin'deki Bedrânî nüshasının başında yer alan risâle neşredilmiş ve bu risâle üzerinden Yûnînînin nüshasını oluşturma sürecine değinilmiştir. Bk. "How al-Buhari’s Sahih was Edited in the Middle Ages", s. 191-222.

27 İbn Hammûye’ye (Serahsî) nispet Hammüvî, telaffuz kolaylı̆̆ıla Hammevî şeklindedir. Günümüz Arap araştırmacılarının tercih ettiği Hammûyî yanlış olmasa da kaynaklardaki yazılışa uymamaktadır. Türkçe akademik metinlerde tercih edilen Hamevî ise Hamalı anlamına geldiğinden yanıltıcı bir kısaltmadır. 
zaten belirttiğinden bu durumu önemsememiştir. Şu bir gerçektir ki birçok nüshada başta yazan isnattan çok metnin hangi nüshadan yazıldığı önemlidir.

Yûnînî, defalarca okuyup tashih etmek suretiyle nüshasının önemini arttırmıştır. Ama onun değerini asıl yükselten husus, bu nüsha ile diğer önemli nüshaların farklarını belirttiği ayrıntılı bir çalışma yapmış olmasıdır.

\subsection{Yûnînînin Kullandığ̣ ve Farklarına İşaret Ettiği Nüshalar}

Yûnînînin çok önem verdiği ve her biri hadis hâfızı olması yönüyle daha fazla itibar ettiği nüshalar şunlardır:

\subsubsection{Ebû Zer Nüshası}

Yûnînî, Ebû Zer (ö. 434/1043) rivayetinde yine bir Hanbelî olan İbn Hutay'e $^{28}$ (478-560) nüshasını kullanmıştır. Bu nüshanın çok titiz bir çalışma olduğunu risâlesinde belirten Yûnînî, bulunduğu bölgede Hanbelîler’in şeyhi olarak kabul edilen Sarîfînîden ${ }^{29}$ (ö. 641/1244) bu nüshayla ilgili övücü sözler nakletmektedir. Ebû Zerr'in râvilerinden Abdülcelîl'in (ö. 459/1067) rivayeti olan İbn Hutay’e nüshasının kopyaları Fas'ta ve Türkiye'de mevcuttur.

Daha önce bahsi geçtiği gibi Ebû Zer, Buhârînin el-Câmiu's-sahîh'ini Firebrî̀nin üç ayrı râvisinden dinlemiş ve aralarındaki farkları nüshasında göstermiştir. Yûnînî kendi nüshasında bu farkların tamamına yakınını aynı rumuzlarla yansıtmıştır.

\subsubsection{Asîlî Nüshası}

Asîlî de (ö. 392/1002) Firebrî̉nin diğger iki râvisinden (Cürcânî ve Mervezî) Buhârîyi semâ‘ etmiş ve bunlar arasındaki farkları nüshasında göstermiştir. Asîlînnin dinlemiş olduğu Cürcânî (ö. 373/983) pek kuvvetli bir râvi sayılmaz, ancak muteber bir Şâfiî fakihi olan ve Şâfiîler’ in “Buhârîyi nakleden râvilerin en üstünü” olarak niteledikleri Mervezînin (ö. 371/981) rivayeti önemlidir.

Asîlî nüshası bu iki râvinin nüsha farklarını göstermesine rağmen ${ }^{30}$ bu farklar zamanla gösterilmemeye başlamıştır. Yûnînî de bu farkları belirtmemiş,

28 Ebü'l-Abbas Ahmed b. Abdullah b. Ahmed b. Hişâm b. Hutay’e el-Lahmî el-Fâsî. Bk. Süyûtî, Hüsnü'l-muhâdara, I, 453.

29 Ebû İshak İbrâhim b. Muhammed b. Ezher el-Irâkī es-Sarîfînî el-Hanbelî. Bk. Zehebî, A 'lâmün-nübelâ', XVI, 332.

30 Kādî İyâz, el-İlmấ, s. 190-91. 
sadece Asîlî ismiyle bu nüshayı nakletmiştir. Farkların belirtilmemeye başlamasında Asîlînnin kullandığı rumuzların -Kādî İyâz’ın ifade ettiği üzere- çok karışık olması da muhtemelen etki etmiştir.

Yûnînînin kullandığı Asîlî nüshası, İbn Abdülber (ö. 463) tarafından nakledilen ve üzerinde hâşiyeleri olan bir nüshadır.

\subsection{3. İbn Asâkir Nüshası}

Çok övülen bir hadis hâfızı olması yönüyle İbn Asâkir'in (499-571) nüshası da Yûnînînin önemsediği diğer bir kaynaktır. İbn Asâkir'in bu nüshası Küşmîhenî ve İbn Şebbûye rivayetlerini içermektedir. ${ }^{31}$ Yûnînînin risâlesinde zikri geçmediği için pek bilinmeyen bu bilgi, Yûnînînin bir kopyasını yazan Nüveyrî tarafından bizzat Yûnînî nüshasından aktarılmıştır. ${ }^{32}$

Yûnînînin kenarda kaydettiği notların birinde "İbn Asâkir'in kendi nüshasında düşmüş olan bir yeri Hammevî (ö. 381/991) ve Nuaymî (ö. 386/996) rivayetlerinden tamamladığını" belirtmesi ${ }^{33}$ de yukarıdaki bilgiyi teyit etmektedir.

İbn Asâkir nüshasında farklar diğerlerinde olduğu gibi ayrıntılı bir şekilde belirtilmemiş olmalı ki Yûnînî çok fazla olmayan bu farkları "İbn Asâkir'de belirtilen bir nüshada" şeklinde yorumlanabilecek "sin" harfi üzerinde "hı" şeklindeki işaretle yansıtmıştır. ${ }^{34}$

\subsubsection{Semânî Nüshası}

Hâfızlı̆̆ılla meşhur olan Abdülkerîm es-Semânî̉ ${ }^{35}$ (506-602), Kerîme rivayetinin olduğu bir nüshayı Ebü'l-Vakt'e okumuş ve böylece iki rivayeti birleştirmiştir. Dımaşk’taki Şümeysâtiyye Hankahı̉na vakfedilen bu nüsha çok meşhur olmuştur. Yûnînî, hâfızlığıyla ve sağlam iş yapmasıyla meşhur olan

31 Küşmîhenî (ö. 389) $\rightarrow$ Habbâzî (372-449) ve Hafsî (ö. 446) rivayeti ile İbn Şebbûye (ö. 376) $\rightarrow$ Ayyâr (ö. 457) rivayeti $\rightarrow$ Furâvî (441-530) $\rightarrow$ İbn Asâkir.

32 Köprülü Ktp., Fâzıl Ahmed Paşa, nr. 362, vr. 296 ${ }^{\text {b }}$ Yûnînînin risâlesinde buna değinmeyişi herhalde nüshasında belirtmiş olması sebebiyledir.

33 Bk. Buhârî, el-Câmiu's-sahîh (Bulak), III, 54 .

34 Yûnînînin elinde birden fazla Asîlî ve Ebû Zer nüshasının olduğu kesindir. Fakat İbn Asâkir nüshasıyla ilgili ikinci bir nüsha açıklaması mevcut değildir. Bu sebeple söz konusu işaretin "İbn Asâkir nüshasının bir kopyasında" anlamına gelmesi zayıf bir ihtimaldir.

Doğrusu İbnü’s-Semânî şeklindedir. Zira müfessir Mansûr es-Semânînin (ö. 489) torunudur. Fakat torun daha meşhur olduğundan ona da Semânî denilmiştir. 
Semânîye işaret etmek üzere $(ظ)^{36}$ rumuzunu kullanmıștır. Kerîme ile Ebü’lVakt karışımı olan kendi nüshasının durumuna çok benzediğinden Yûnînî bu nüshayı ayrıca önemsemektedir. Ama bu nüshada Kerîme-Ebü’l-Vakt ayırımı net değildir, daha çok "bir nüsha" şeklinde nakiller mevcuttur.

Yûnînî bütün bu nüshalar arasındaki farkları, çoğu zaman bir harf farkı da dahil olmak üzere büyük bir emekle göstermiş ve böylece aynı anda beş nüshayı birden aktarmıştır. Bunun yanında, kritik yerlerde senetlerle ilgili değerlendirmeleri Ebû Ali el-Ceyyânî (427-498) ve Kādî İyâz'dan (476544), dille ilgili değerlendirmeleri de Cevherî (ö. 400/1009) ve İbn Sîde’den (ö. 458/1066) nakletmek suretiyle nüshasının önemini arttırmış ve haklı bir şöhrete kavuşmuştur.

\section{Yûnînî Nüshasının Kopyaları (Fürû́')}

Yûnînînin asıl nüshasının günümüzdeki âkıbeti bilinmemektedir. En son kopyasını yazan Abdullah b. Sâlim'den sonraki bilgiler Hindistan bölgesini işaret ettiğinden, eğer günümüze ulaşabilmişse bu nüshanın Hindistan'da olması mümkündür. Yûnînînin kopyalarına geçmeden önce kopya/fer' ifadesi üzerinde durmamız gerekmektedir.

Fer' denilen ve "asl"dan yapılan çoğaltmalar, doğrudan asıl nüshadan yapılanlar ve diğer kopyalardan yapılanlar olmak üzere ikiye ayrılır. Önemli olan, doğrudan asıldan yapılan çoğaltmalardır. Bu çalışmada tanıtılacak olan kopyalar/fürû́, bir istisna dışında asıldan yazılmış olan ve nüshalar arası farklarla beraber kenarlardaki diğer izahları da tamamıla -ya da neredeyse tamamıyla- aktaran nüshalardır. Bunlardan özellikle titiz bir şekilde yazılmış olanlar asıl olma özelliğini kazanmış ve biraz sonra tanıtacağımız gibi Yûnînî nüshası (asl) demeyi haketmiş kopyalardır.

Bunlardan farklı olarak bir de Yûnînî nüshasındaki rumuzları kullanarak nüsha farklarını yansıtan nüshalar vardır. Özellikle Ebü’l-Vakt rivayetini içeren nüshalarda bu durum yaygındır. Bu nüshalar Yûnînîden kopya edilerek yazılmış değillerdir. Ancak Ebüll-Vakt rivayeti olduklarından, Yûnînînin herhangi bir kopyasından nüsha farklarını aynı rumuzlarla aktarmışlardır. Yûnînî nüshasının kopyası veya kopyasının kopyası olduğuna dair herhangi bir açıklama içermeyen bu tür nüshalar bu çalı̧̧maya dahil edilmemiştir.

Asıl olma özelliği kazanan nüshalardan Abdullah b. Sâlim nüshası bu çalışmanın temel konularından birini teşkil ettiğinden bir sonraki ana başlıkta

36 Bu rumuzun başka bir rumuzla karışma tehlikesi olmadığı için olsa gerek Yûnînî nüshasının çoğu yerinde (b) şekline dönüşmüştür. 
müstakil olarak ele alınacak ve diğerlerine göre daha ayrıntılı bir değerlendirmeye tâbi tutulacaktır. Abdullah b. Sâlim nüshası dışındaki diğer fer' nüshalar şunlardır:

\subsection{Nüveyrî Nüshası}

Ahmed b. Abdülvehhâb b. Muhammed el-Bekrî en-Nüveyrîi ${ }^{37}$ (677-733), Yûnînînin hem talebesi olması hem de nüshasını asıldan yazması yönüyle önem arzetmektedir. Tespit edebildiğimiz kadarıla Türkiye'de biri 720, ${ }^{38}$ diğeri $725^{39}$ tarihli olmak üzere Nüveyrînnin yazdığı iki nüsha mevcuttur. Ana metni açısından Abdullah b. Sâlim nüshası kadar açık ve net yazılmamış olsa da, İbn Zeyd'in kaleme aldığı asıl nüshanın sonunda bulunan ve bu asıl nüshayla ilgili tanıtıcı bilgiler içeren notları ${ }^{40}$ ve kenardaki kırmızı yazıları ${ }^{41}$ aynen nakletmesi açısından bu nüsha eşsiz konumdadır.

Nüveyrî, Zebîdî (Ebü'l-Vakt) rivayetini hocası Yûnînîden başka iki meşhur isimden ${ }^{42}$ daha semâ‘ etmiş ve bu isimleri nüshasının başındaki isnatta zikretmiştir.

\subsection{Mekkî Nüshası}

İbrâhim el-Mekkî b. Ali el-Kaysarî el-Hanefînin 1117 yılında Mekke'de, İbn Zeyd'in yazdığı asıl nüshadan doğrudan naklettiği bu kopya Fas'tadır. ${ }^{43}$ Bu nüshayı satın alıp Fas’a götüren Ahmed b. Nâsır ed-Dirî̉nin 1128'de

37 Bk. Süyûtî, Hüsnül-muhâdara, I, 556.

38 Edirne Selimiye Ktp., nr. 1042.

39 Köprülü Ktp., Fâzıl Ahmed Paşa, nr. 362. Bu nüsha M. Mustafa el-A'zamî tarafından tıpkıbasım yapılmak suretiyle neşredilmiştir (Riyad: Dârü’l-A'zamî, 1434/2013).

$40 \mathrm{Bu}$ bilgiler içerisinde, İbn Zeyd'in yazdı̆̆ nüshanın tek cilt olduğu haberi de geçmektedir. Ama bunun kendi içinde iki cilt şeklinde olduğu, Yûnînînin ilk cildinin bittiği yerdeki (Buhârî, el-Câmiu's-sahîh [Bulak], IV, 146 = Buhârî, el-Câmiu's-sahîh [A'zamî], s. 266) "Yûnînînin aslındaki ilk cildin sonudur" ifadesinden anlaşılmaktadır. Bu durumda Kastallânînin şerhinde anlattığı "ayrı iki cilt” durumu (İrşâdü̉s-sârî, I, 40-41) herhalde nüshanın zamanla ikiye bölünmesiyle oluşmuştur.

41 Aslın aslıyla ilgili olan kırmızı yazılar konusu Yûnînînin ana metniyle ilgili bölümde geçmişti.

42 Sittü’l-Vüzerâ adıyla mâruf Vezîra bint Ömer b. Es'ad b. Müneccâ et-Tenûhiyye (624716) ve el-Haccâr adiyla mâruf Şehâbeddin Ebü’l-Abbas Ahmed b. Ebû Tâlib b. Ebü’nNiam es-Sâlihî (625-730) için bk. Fâsî, Zeylü't-Takyîd, I, 317; II, 397.

43 Rabat, el-Hizânetü'l-âmme, nr. 481 ق. Bk. Menûnî, "Sahîhu'l-Buhârî fi'd-dirâsâti'lmagribiyye", s. 528 . 
bu nüshadan yazdırdığı bir kopya da yine Fas'ta mevcuttur. ${ }^{44}$ Abdullah b. Sâlim'in kaynaklarından biri olma ihtimali sebebiyle ileride bu kopyadan tekrar bahsedilecektir.

\subsection{Muhammed el-Mizzî Nüshası}

Şemseddin Muhammed b. Ahmed b. Safî b. Kāsım el-Mizzî el-Harîrî elGazûlî̀ $^{45}$ (697-777) tarafından yazılan bu kopya, Kastallânînin esas aldı̆̆ı ve "neredeyse aslını geçmiş"46 diyerek övdüğü bir nüshadır. Yûnînînin aslından ve iki kopyasından ${ }^{47}$ yazılan bu nüsha da her ayrıntıyı aktarmakla meşhurdur. Mısır'da Tenkīziyye Medresesi’ne vakfedildiği için “Tenkīziyye kopyası" (el-fer'u't-Tenkizîl) adıyla da bilinen bu nüshanın II. cildi Mısır'dadır ve Menûnînin naklettiğine göre bu yazma Gazûlînin 735 yılında yazdığ́ nüshadır. ${ }^{48}$ Türkiye'de nüshanın tamamını içeren bir kopyası mevcuttur. ${ }^{49}$

\subsection{Muhammed b. İlyâs Nüshası}

748 yılında Muhammed b. İlyâs b. Osman el-Mutasavvıf tarafından yazılan bu nüshanın Yûnînînin bir kopyası olduğu belirtilse de asıldan kopya edilmediği kesindir. Çünkü nüshada "Yûnînî nüshasıyla mukabele edilmiş bir nüshayla karşılaştırıldığı" notu mevcuttur. ${ }^{50}$ Ayrıca Mizzî (ö. 742/1341) ve Zehebînin (ö. 748/1347) tashih ettiği bir nüsha ile Ahmed es-Sübkînin (ö. 773/1372) ve Alâeddin İbnü’t-Türkmânînin (ö. 750/1350) tashih ettiği başka bir nüshayla da mukabele edildiği belirtilmektedir. Asıldan kopya edilmeyen bu nüshayı burada özellikle zikretmemizin sebebi ileride göreceğimiz gibi Bulak baskısında bu nüshanın da kullanılmış olmasıdır. Bu nüsha Kahire'de mevcuttur. ${ }^{51}$

44 Hizânetü Temgrut, nr. 949. Bk. Menûnî, “Sahîhu’l-Buhârî fi'd-dirâsâti'l-magribiyye”, s. 528-29.

45 Bk. Fâsî, Zeylütt-Takyîd, I, 46.

46 Kastallânî, İrşâdüs-sârî, I, 41.

47 Hacı Mâlik Medresesi’nde vakfedilen bu iki kopya hakkında bilgi verilmemiştir.

48 Dârü'l-kütübi'l-Misriyye, nr. 177. Bk. Menûnî, "Sahîhu'l-Buhârî fi'd-dirâsâti'lmagribiyye", s. 533.

49 Süleymaniye Ktp., Kılıç Ali Paşa, nr. 263. İleride değineceğimiz gibi, bu nüshaya başka nüsha bilgileri de eklenmiştir. Bu nüshadaki kayda göre Muhammed el-Mizzî asıl nüshayı 747 yılında yazmıştı. Bu kayıtta bir yanlışlık yoksa Mizzînin de benzerlerinde görüldüğü gibi birkaç nüsha yazdığı anlaşılmaktadır.

50 Menûnî, “Sahîhu'l-Buhârî fi'd-dirâsâti'l-magribiyye”, s. 533.

51 Dârü'l-kütübi'l-Misriyye, nr. 1108-1109. 


\subsection{Bedrânî Nüshası}

Muhammed b. Hasan el-Bedrânîn ${ }^{52}$ (787-837), Ebû Züra el-Irâkỉden (ö. 826/1422) Sahîh-i Buhârîyi semâ‘ etmiștir. Ondan dinlediği bu nüshayı 831'de Yûnînînin aslıyla karşılaştırmış ve onun notlarını kendi nüshasına eklemiştir. Böylece nüshası da Yûnînî kopyası olmuştur. ${ }^{53} \mathrm{Bu}$ nüshanın başında, Yûnînînin Usûl/Rumûz ismiyle bilinen ve kullandiğı nüshalarla sembolleri açılkayan risâlesi de bulunmaktadır. Aslı Mısır'da bulunan bu nüshanın Türkiye kütüphanelerinde kopyaları mevcuttur. ${ }^{54}$

Bedrânî nüshasının, başında bulunan ve hocası Ebû Zürádan dinlediği üç ayrı rivayeti (Ebü'l-Vakt, Kerîme, Ebû Zer) zikreden senet sebebiyle bu üç rivayeti içerdiği zannedilse de ${ }^{55}$ gerçekte tek bir nüshadır ve o da Yûnînînin rumuzlarını kullanmaya müsait olan Ebü’l-Vakt rivayetidir. Yalnız Ebû Züra’nın tashih ettiği yerler de mevcuttur. Bedrânî nüshası İbn Ebû Râfi ${ }^{56}$ nüshasıyla mukabele edilmiş olup ileride örneklerini göreceğimiz gibi, nüsha içerisinde İbn Ebû Râfi‘ nüshasının farkları belirtilmektedir.

Yûnînînin en önemli fer'i olan Abdullah b. Sâlim el-Basrî nüshasına geçmeden, diğer bir Yûnînî nüshasından daha bahsetmek gerekmektedir. Yûnînî rumuzlarını / nüsha farklılıklarını aktaran bu nüsha İbn Hacer'in övdüğ̈ ${ }^{57}$ İsmâil b. Ali el-Bikāî (ö. 806/1404) nüshasıdır. Aslının Mısır'da olduğu belirtilen ${ }^{58}$ bu nüshanın bir kopyası Türkiye'dedir. ${ }^{59}$ Bikāî nüshası, başında verilen

52 Bk. Ziriklî, el-A 'lâm, VI, 87.

53

قürkiye’deki bir nüshasının sonunda şu ifade geçmektedir: قوبلت على الأصل اليونيني فصحّت لصحتّها.

54 Âtıf Efendi Ktp., nr. 579-80; Süleymaniye Ktp., Hac1 Beşir Ağa, nr. 161; Yazma Bağışlar, nr. 1557.

55 Abdülhalîm, Rivâyâtüll-Câmii's-sahîh, s. 378.

56 Nüshanın sonundaki açıklamada İbn Ebû Râfi‘ olarak geçerken, nüsha içerisindeki bazı notlarda İbn Râfic olarak zikredilmektedir. Bize göre bu isim, İbn Râfi diye meşhur olan Kahireli Ebü'l-Meâlî Takıyyüddin Muhammed b. Râfi ' es-Sellâmî esSümeydî (704-774/1372) olabilir. Her ne kadar tarihçi kimliğiyle öne çıksa da aynı zamanda hadis hâfızıdır. Konumuz olan Bedrânînin Sahîh’i dinlediği hocası Ebû Zür'a el-Irâkī (762-826) çocuk yaşta İbn Râfíden hadis dinlemiş, babası Zeynüddin el-Irâkī (725-806) ise onun talebesi olmuştur (bk. Kandemir, "İbn Râfi”, s. 239). Fakat izah kısmında İbn Ebû Râfi' olarak geçtiğinden biz de bu şekilde naklettik.

Bk. el-Câmiu’s-sahîh (Kahire), I, 154.

58 el-Câmiu's-sahîh (Kahire), I, 154.

59 Köprülü Ktp., Fâzıl Ahmed Paşa, nr. 355. Bu nüshanın kopya olduğuna dair hiçbir kayıt yoktur. Aslının Mısır'da olduğu bilgisi doğruysa, elimizdeki nüsha "kopya olduğu belirtilmeyen" bir kopya olmaktadır. 
senet de dahil İbnü’s-Serrâc’in (705-782) Yûnînînin aslından yazdığı nüshasının kopyasıdır. ${ }^{60}$ Doğrudan asıldan aktarılmadığından ve Yûnînînin önemli notlarını içermediğinden burada bir başılı yapmadığımız bu nüshaya ileride tekrar temas edilecektir ${ }^{61}$

\section{Abdullah b. Sâlim (Basrî) Nüshası}

Mekke'de yaşayan ve Yûnînî nüshasını aslından yazan Abdullah b. Sâlim el-Basrî́62 (1049-1134/1722), ulaşabildiği Yûnînî kopyalarını da dikkate almış ve kimi zaman oluşan asıl ile kopyalar arasındaki farkları veya bu kopyalardaki kayıtları da nüshasında aktarmıştır. Bunun yanında, Yûnînînin kritik yerlerde yaptığı nakilleri aynen yansıttığı gibi kendisi de ihtilâflı veya yanlış olma ihtimali bulunan yerlerde şeyhülislâm olarak çokça zikrettiği İbn Hacer'den ve Kastallânîden nakillerde bulunmuş, bu yönüyle Yûnînî nüshasına değer katmıştır. Hakkında nakledilen bilgilerden ve Türkiye'deki kopyalarından anladığımız kadarıyla güzel bir yazıyla yazdığı nüshasındaki bu bilgileri hiçbir karışıklığa mahal vermeden büyük bir titizlikle nakletmesi de nüshanın önemini arttıran diğer bir husustur.

Abdullah b. Sâlim, Yûnînînin aslıyla karşılaştırdığ i iki kopyadan birine hiçbir isim vermemekte, ${ }^{63}$ diğerine ise "Mekkî kopyası" (el-fer'u'l-Mekkî) demektedir. Bunun, bir önceki bölümde bahsettiğimiz ve Mekkî nüshası diye isimlendirdiğimiz İbrâhim el-Mekkînnin Yûnînî kopyası olması kuvvetle muhtemeldir. ${ }^{64}$ Abdullah b. Sâlim, Sahîh-i Buhârî̀ye yazmış olduğu ama ta-

6o İbnüs-Serrâc olarak tanınan İmâdüddin Ebû Bekir b. Ahmed ed-Dımaşkī, Haccâr’ın ve Hâfız Mizzînin talebesidir. Bk. İbn Hacer, İnbâül-gumr, I, 222.

61 A‘zamînin naklettiğine göre Şeyh Nizâm Ya‘kūbî, Türkiye’deki Bikâî nüshasının tıpkıbasımını yapmıştır. Bk. el-Câmiu’s-sahîh (A‘zamî), s. 3 .

62 Sahîh-i Buhârî metni başta olmak üzere Kütüb-i Sitte metinleri üzerine yaptığ 1 çalışmalarıyla tanınan Abdullah b. Sâlim el-Basrînin hangi ilim ve eserden icâzetli olduğunu ve kimlerin eğitiminden geçtiğini, el-İmdâd bi-ma'rifeti ulüvvi'l-isnâd isimli sebet türünde kaleme alınan eserde oğlu Sâlim ifade etmektedir. Bk. Sâlim b. Abdullah b. Sâlim el-Basrî, el-İmdâd bi-ma'rifeti ulüvvil-isnâd, Haydarâbâd 1328. Bu çalışma üzerinden Abdullah b. Sâlim'in hadisçiliği ve XVIII. yüzyılda hadis ilmi üzerine yapılan birtakım değerlendirmeler için bk. Woll, “Abdullah b. Sâlim el-Basrî”, s. 217-30.

63 İleride göreceğimiz gibi Abdullah b. Sâlim’in doğrudan Muhammed el-Mizzîden nakil yaptığı bir yeri dikkate alırsak, ismini zikretmediği bu kopyanın Mizzî nüshası olabileceğini düşünebiliriz.

64 Fas'taki bu nüsha ile Abdullah b. Sâlim’in "Mekkî kopyası" notları arasında yapılacak bir karşılaştırma bu durumu netleştirecektir. 
mamlayamadığg şerhte de "Yûnînînin aslı", "Yûnînînin kopyası" ve "birçok asıl" ifadelerini kullanmaktadır. ${ }^{65}$

Kettânî (1886-1962), Basrînnin Yûnînî aslına nasıl ulaştığına dair şu bilgiyi kaydetmektedir: Yûnînînin asıl nüshası bir şekilde, Mağribli olup Mekke’de yaşayan Rûdânînin (ö. 1094/1683) eline geçmiştir. ${ }^{66}$ Ondan bu nüshayı Hintli olup Mekke'de yaşayan Muhammed Ekrem b. Muhammed almış, Abdullah b. Sâlim de bu nüshayı ödünç alıp istinsah etmiştir. Aynı yerde, Basrî nüshasının âkıbetiyle ilgili bazı bilgiler de aktaran Kettânî, Şeyh Tâhir Sünbül'le ${ }^{67}$ (12451343/1926) Medine'de karşılaştı̆̆ını, onun elinde Basrî nüshasını gördügünü ve onun bu nüshayı Bulak (Sultâniye) baskısının tashihi için Âsitâne'ye (İstanbul) götürmüş olduğunu nakletmektedir. ${ }^{68}$

Bu bilgiden çıkardığımız sonuç, Abdullah b. Sâlim’in asıl nüshasının Bulak baskısı için getirildiği ve büyük bir ihtimalle bu baskıda kullanıldığıdır. Bu nüshanın geri gittiği de -çünkü Kettânî nüshayı bizzat gördüğünü söylemektedir- bu nakilden anlaşılmaktadır. Fakat nüshanın Türkiye'de kaldığı süre içerisinde ve Hicaz'da epey sayıda kopyası yazılmıştır.

Türkiye'deki Basrî nüshalarının çoğunda Abdullah b. Sâlim’le ilgili hiçbir kayıt mevcut değildir. Bu nüshaların Abdullah b. Sâlim nüshasının kopyaları olduğunu netleștiren husus, Yûnînînin aslı ile kopyaları arasında çokça yapılan karşılaştırmalar ve ileride örneklerini vereceğimiz gibi Bulak baskısının bu nüshadan belirterek veya belirtmeden yaptığı nakillerle bu nüshadaki notların uyumudur. Çünkü bu ifadeler, Yûnînînin aslında bulunan ve herhangi bir Yûnînî kopyasında da bulunabilecek yorumlar değildir; bilakis kopya sahibinin, hem de Kastallânîden (ö. 923/1404) sonra yaşamış bir kopya sahibinin ifadeleri ve nakilleridir. Bazı nüshalarda ise durum daha nettir ki ilk bulduğumuz nüsha ile son bulduğumuz nüsha bu kabildendir.

Konya Yûsuf Ağa Kütüphanesi'ndeki ${ }^{69}$ nüsha, ilk bulduğumuz ve bir süre Basrînnin asıl nüshası zannettiğimiz fakat Ezherliler'in yaptığı bazı nakillerle uyum göstermediğinden bir kopya olduğuna karar kıldığımız

65 Basrî, Ziyâü's-sârî, I, 156, 301; XV, 394.

66 Muhammed b. Süleyman er-Rûdânî, hadisle ilgili senetlerinde Yûnînî tarikini de zikretmektedir. Bk. Silatül-halef, s. 45-46.

67 Bilgi için bk. "Nesebü âileti Âli Sünbül", http://alansab.net/forum/archive/index. php/t-238.html (16.03.2016).

68 Kettânî, Fihrisü'l-fehâris, I, 199.

69 nr. 5555. 
nüshadır. Bu nüsha da diğerleri gibi Ebü'l-Vakt senediyle ${ }^{70}$ başlamaktadır ama zahriyede diğerlerinden farklı olarak Abdullah b. Sâlim'in oğlu Sâlim’in (ö. 1160/1748) babası aracıllğıyla Buhârîye ulaşan ve dünyadaki en kısa senet olarak kabul edilen ama bu nüsha açısından ilmî bir değeri olmayan senet zikredilmektedir. ${ }^{71}$

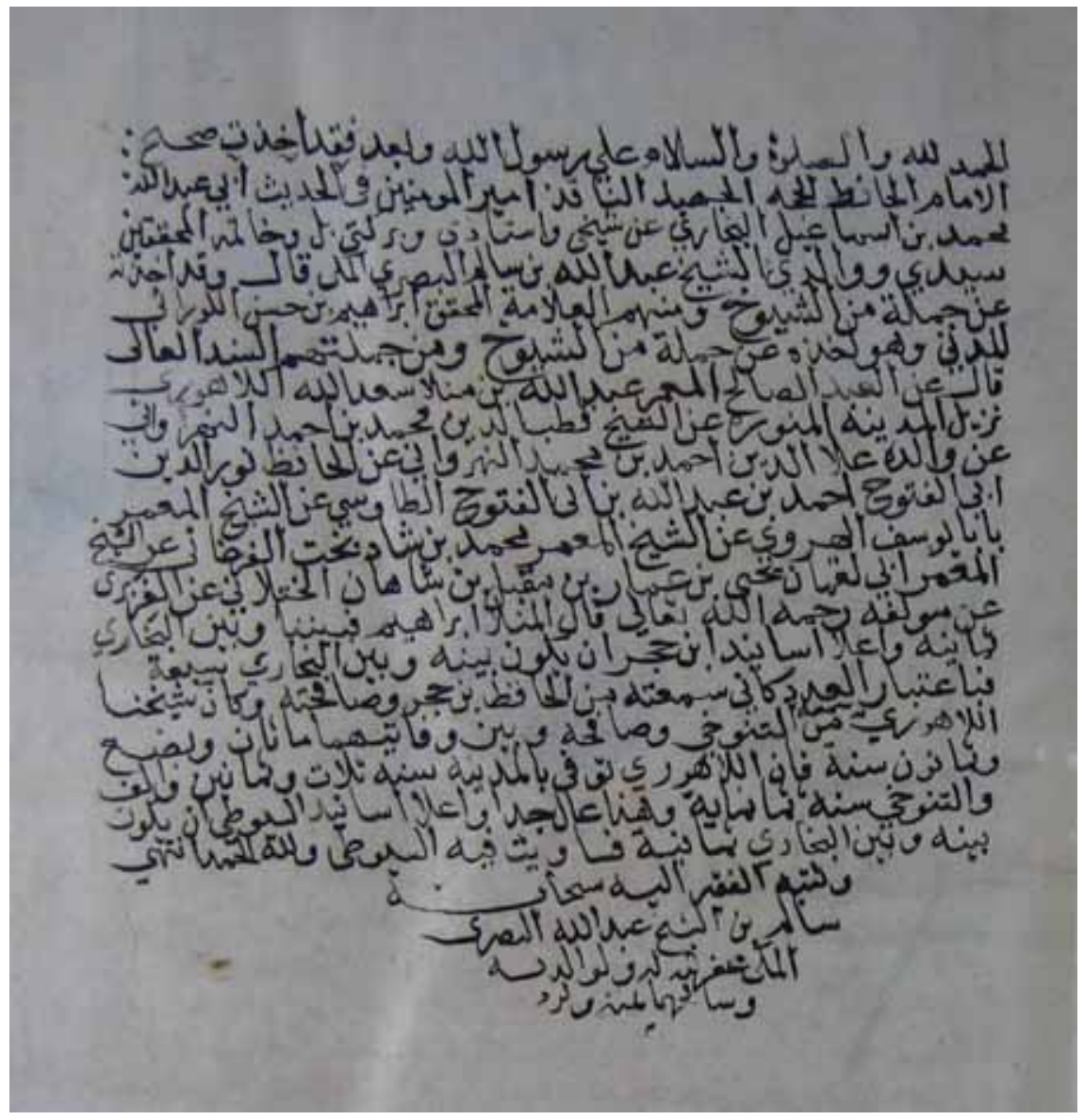

70 Basrî nüshasının başında ve Yûnînînin II. cildine denk gelen yerde (Konya Yûsuf Ağa Ktp., nr. 5555, vr. 288 ${ }^{\text {a }}$ Ebü'l-Vakt ile başlayan senet vardır. Ezherliler sadece II. cilttekini aktarmışlardır. Bk. Buhârî, el-Câmiu's-sahîh (Bulak), IV, 146.

71 Yazılı bir nüshayı naklederken kapağa yakın bir yerde ayrıca bir senedin zikredilmesi tamamen bir formalitedir. Fakat bu geleneği önemseyenler, naklettiği nüshanın başka bir tarik olduğuna bakmaksızın kendi semâ‘ ettiği senedi zikretmeyi tercih etmişlerdir. Ebû Zer senediyle başlayan kimi nüshaların ilk sayfasına müstensih tarafından Ebü’l-Vakt senedi konması bundandır. Basrînin oğlunun aktardığı senet de ne Yûnînî ne de Ebü’l-Vakt ile alâkalıdır. Zaten Sâlim, "Birçok senedimiz var" deyip en kısasını nakletmeyi tercih etmiştir. 


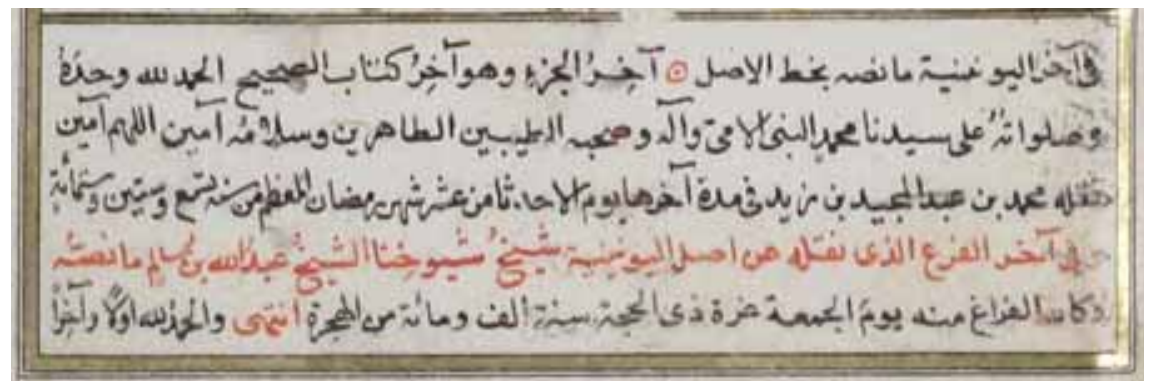

En son bulduğumuz nüsha ${ }^{72}$ ise daha nettir. Çünkü bu nüshanın son kısmında önce Yûnînî nüshasının sonunda ne yazdığı aktarılmakta, ardından da "Şeyhlerimizin şeyhi Şeyh Abdullah b. Sâlim’in Yûnînî nüshasının (Yûnîniyye) aslından naklettiği kopyanın sonunda şu metin vardır" diyerek Abdullah b. Sâlim’in bu nüshayı 1100 yılında yazdığı kaydı nakledilmektedir. $^{73}$

Ahmed Muhammed Şâkir'in bahsettiği ama Basrî nüshası olduğunu farkedemediği diğer bir kopya Muhammed es-Sâbir isimli bir müstensih tarafından 1218 'de yazılmıştır. ${ }^{74} \mathrm{Bu}$ nüshanın giriş kısmında nüshaya bazı hâşiyeler ekleyen Abdullah Mîrganî (?) isimli şahıs "Abdullah b. Sâlim’in ve diğerlerinin Yûnînî nüshasıyla ilgili olarak nahiv kaidelerine uymayan bazı nakillerde bulunduğu" açıklamasını yapmaktadır. Bu nüshada Basrînin notları da kimi zaman "Basrî”" kaydıyla bitmektedir.

Abdullah b. Sâlim'in izahlarını eksiksiz içeren Topkapı Sarayı Müzesi Kütüphanesìnde tespitini yaptığımız bir başka kopya nüsha ise henüz Abdullah b. Sâlim’in hayatta olduğu bir döneme tekabül eden 1114 istinsah tarihi ile dikkat çekmektedir. ${ }^{75}$ Ancak müstensihi hakkında bilgi bulunmamaktadır.

Abdullah b. Sâlim'in birkaç kopyasını da Menûfî isimli bir şahıs Mekke’de yazmıştır. Tarih olarak Abdullah b. Sâlim'in yaşadığı devrin hemen sonrasına tekabül eden bu kopyalardan hem Menûfînin istinsah ettiği hem de Menûfîden istinsah edilmiş olan nüshalar Türkiyede mevcuttur. ${ }^{76}$

72 Konya Bölge Yazma Eserler Ktp., nr. 8980.

73 Bu bilgi elimizdeki bütün Basrî nüshalarının birer kopya olduğunu ortaya koyan diğer bir husustur. Çünkü erişebildiğimiz nüshaların hiçbiri bu kayıtta ifade edildiği gibi sona ermemektedir.

74 Bursa İnebey Ktp., Ulucami, nr. 539. Antepli olan bu müstensih altı tane Basrî nüshası yazmıştır. Ahmed Muhammed Şâkir' in elinde olan, 1215'te yazılan nüshanın II. cildidir.

75 Topkapı Sarayı Müzesi Ktp., III. Ahmed, nr. 250.

76 Menûfînnin istinsah ettiği 1144 tarihli Abdullah b. Sâlim nüshasının bir kopyası için bk. Süleymaniye Ktp., Ayasofya, nr. 778. Bu şahsın ayrıca Basrînin notlarını içermeyip 
Bazı Basrî kopyalarında nâdiren geçen notlarda da "Abdullah b. Sâlim nüshasında böyledir" açıllaması mevcuttur. ${ }^{77}$

Abdullah b. Sâlim'in açıklamalarını kısmen içeren nüshalar da vardır. ${ }^{78}$

Abdullah b. Sâlim kopyalarından aktaracağımız diğer bilgiler, "Bulak Baskısında Kullanılan Nüshalar" kısmında gelecektir. ${ }^{79}$

\section{Yûnînî Nüshasının Bulak'ta Basılması (en-Nüshatü's-Sultâniyye)}

Sultan II. Abdülhamid, 4 Şâban (1) 311 tarihli bir tahrirat ile Ezher meşâyihine bir emirnâme eşliğinde Yûnînî nüshasını göndermiş, ${ }^{80}$ onlar da titiz bir çalışma ve tashihle Emîriyye Matbaası̉nda bu basımı gerçekleștirmişlerdir (1311-1313). Sonraları "Sultâniyye nüshası" (en-Nüshatüs-Sultâniyye) diye anılacak olan bu baskı, Osmanlı ve Ezher sebebiyle en meşhur Buhârî neşri olmuştur. Hemen akabinde yine Osmanlı Devleti eliyle İstanbul'da basılan nüsha bile ${ }^{81}$ Bulak baskısının gerisinde kalmıştır.

Abdülhamid'in, Yûnînî nüshasının aslını gönderdiği söylense de $\mathrm{e}^{82}$ onun Misır’a gönderdiği nüsha, daha önce belirttiğimiz gibi Abdullah b. Sâlim’in Yûnînî kopyasıdır. Baskıda kullanılan nüshanın Yûnînî aslı değil de Abdullah b. Sâlim kopyası olduğu hem bu neşirdeki mukaddimeden ${ }^{83}$ hem de kenardaki notlardan anlaşılmaktadır. Biraz sonra yapacağımız karşılaştırmalı nakillerle bu durum net olarak ortaya konacaktır.

sadece Yûnînî rumuzunu / nüsha farklarını içeren Yûnînî kopyaları da mevcuttur. Bk. Râgıb Paşa Ktp., nr. 335.

77 Bk. Süleymaniye Ktp., Ayasofya, nr. 778, vr. $631^{\text {b }}$.

78 Süleymaniye Ktp., Denizli, nr. 52; Amasya Beyazıt Yazma Eser Ktp., nr. 199; Beyazıt Yazma Eser Ktp., Veliyyüddin Efendi, nr. 501.

79 Kettânînin Şeyh Tâhir Sünbül'ün elinde gördügünü ifade ettiği Basrî nüshasının aslıyla ilgili kullandığı şu ifade, Türkiye'deki Konya Yûsuf Ağa (nr. 5555); Konya Bölge Yazma Eserler (nr. 8980); Süleymaniye (Hamidiye, nr. 214; Fâtih, nr. 1059) kütüphanelerindeki nüshalardaki durumu da aynen yansitmaktadır: نهاية في الصحة والمقابلة والضبط والخط الواضح.

8o Başbakanlık Osmanlı Arşivi, Y. PRK. MK. 6/89.

81 Haz. Mehmed Zihni Efendi, İstanbul: Matbaa-i Âmire, 1315.

82 Bk. Sezgin, Buhârînin Kaynakları, s. 199; Menûnî, "Sahîhu’l-Buhârî fi'd-dirâsâti'lmagribiyye", s. 535 .

83 Bk. Mukaddime, s. 3. 


\section{Baskıda Kullanılan Yûnînî Yazmaları ve Diğer Nüshalar}

Bulak baskısını yapanlar, kullandıkları Yûnînî kopyalarını ve diğer nüshaları belirtmemişlerdir. Bu sebeple, "kullanılan nüshalar" konusu kenarlardaki notlardan anlaşılmaya çalışılmaktadır.

Biz daha önceki çalışmalarda zikredilen bilgileri tekrarlamak yerine, kenardaki notları ayrıntılı bir şekilde incelemeyi ve eldeki yazma nüshalarla karşılaştırma yapmayı tercih ettik. Çünkü Ezherliler'in kendi ifadeleriymiş gibi yaptıkları açıklamalardan yanlış sonuçlar çıkarmak mümkündür.

Bir hâmişte "Elimizdeki üç kopyada da yoktur" denilmektedir. ${ }^{84} \mathrm{Bu}$, ellerinde en az üç kopyanın olduğunu göstermektedir. Kopya / fer" kelimesinin kullanıldığı diğer notlara baktığımızda ise toplamda dört fer' çıkmaktadır. Ancak bu dördüncüsünü Yûnînî kopyası mı yoksa ayrı bir nüsha mı olarak gördükleri net değildir. Çünkü Ezherliler "Elimizdeki kopyada ve güvenilir nüshalarda" ifadesini de sıkça kullanmakta ve birazdan aktaracağımız gibi kimi zaman bu nüshalardakini metne almaktadırlar. Aşağıda bu dört nüshadan ve tespit edebildiğimiz diğer nüshalardan yapılan nakiller incelenecektir.

\subsection{Abdullah b. Sâlim Nüshası}

Ezherliler özellikle II. ve IX. ciltlerde, esas aldıkları nüshanın Abdullah b. Sâlim nüshası olduğunu belli eden ifadeler kullanmışlardır. ${ }^{85}$

Örnek 1:

\begin{tabular}{|l|l|}
\hline $\begin{array}{l}\text { Bulak baskısı, } \\
\text { IX, 84 }\end{array}$ & Konya Yûsuf Ağa Ktp., nr. 5555, vr. 572 \\
\hline & $\begin{array}{l}\text { Açıklama: Ezherliler'in belirttiği gibi elimizdeki Basrî } \\
\text { nüshasında id kelimesinin üzeri çizilidir ve kenarda da } \\
\text { bunu açıklayan not vardır. }\end{array}$ \\
\hline
\end{tabular}

84 Buhârî, el-Câmiu's-sahîh (Bulak), I, 112.

85 Abdullah b. Sâlim nüshasından vereceğimiz örnekler, makale boyutunu aşmamak için sinırlı sayıda tutulmuştur. 
Örnek 2:

\begin{tabular}{|c|c|}
\hline $\begin{array}{l}\text { Bulak baskisi, } \\
\text { IX, } 84\end{array}$ & Konya Yûsuf Ağa Ktp., nr. 5555, vr. 572 \\
\hline 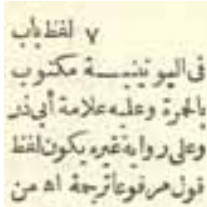 & 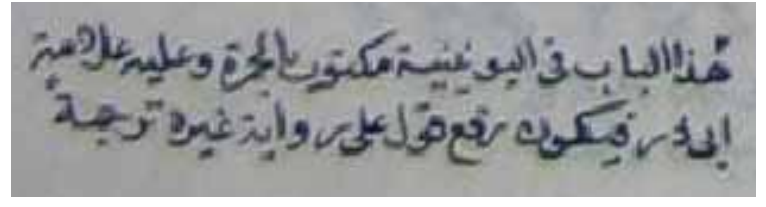 \\
\hline 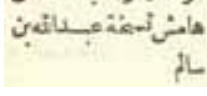 & $\begin{array}{l}\text { Açıklama: Basrî burada باب kelimesi olduğu halde قول kelimesinin merfû okunuşunu izah etmektedir. } \\
\text { قبان }\end{array}$ \\
\hline
\end{tabular}

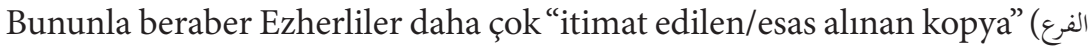
الذي يعوّل عليه , الفرع الذي بيدنا) "elimizdeki kopya" da "asildaki dipnottan-kopyadaki dipnottan” (من هامش الأصل من هامش الفرع) türü ifadelerle Basrî nüshasından nakillerde bulunmuşlardır.

Örnek 3:

\begin{tabular}{|c|c|}
\hline Bulak baskısı, II, 73 & Konya Yûsuf Ağa Ktp., nr. 5555, vr. 99b \\
\hline 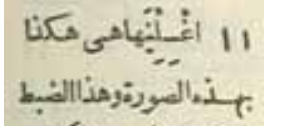 & 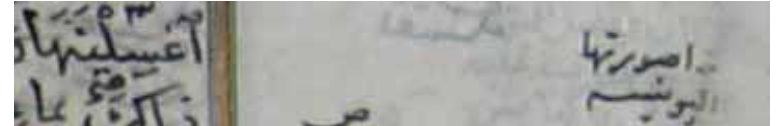 \\
\hline 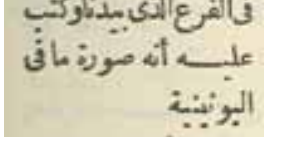 & $\begin{array}{l}\text { Açılklama: Yûnînî nüshasında bir kelimenin hem tekil } \\
\text { hem de çoğul hali beraber kaydedildiğinden } \\
\text { Basrî, asılda böyle olduğunu belirtmektedir. }\end{array}$ \\
\hline
\end{tabular}

Örnek 4:

\begin{tabular}{|c|c|}
\hline $\begin{array}{l}\text { Bulak baskısı, } \\
2 / 140\end{array}$ & Yusuf Ağa Ktp., nr. 5555, vr. 226a \\
\hline 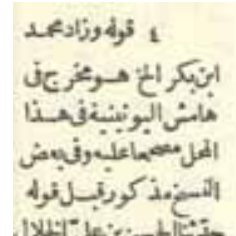 & 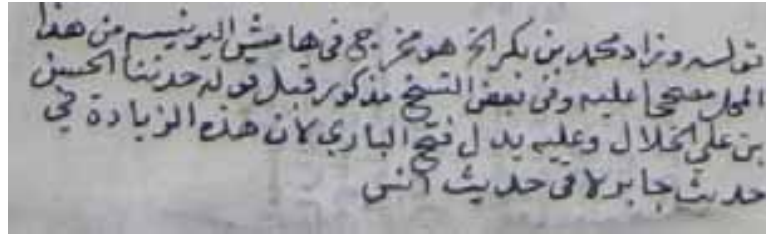 \\
\hline 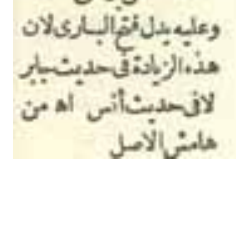 & $\begin{array}{l}\text { Açıklama: Basrî burada Fethu’l-bârîdeki ifadeleri } \\
\text { de dikkate alarak وزاد diye başlayan mütâbaatın } \\
\text { Yûnînînin asıl nüshasında yanlış yerde olduğunu be- } \\
\text { lirtmektedir. Burada görüldüğü gibi Ezherliler Basrî } \\
\text { nüshası için "asl” ifadesini kullanmaktadırlar. }\end{array}$ \\
\hline
\end{tabular}


Ezherliler, Basrînin İbn Hacer, Kastallânî ve diğerlerinden naklettiği bilgileri ya doğrudan nakletmekte ya da asıl kaynaklara dönerek oradan aktarmaktadırlar.

Örnek 5:

\begin{tabular}{|c|c|}
\hline Bulak baskısı, IX, 109 & $\begin{array}{l}\text { Konya Yûsuf Ağa Ktp., nr. 5555, } \\
\text { vr.581 }\end{array}$ \\
\hline 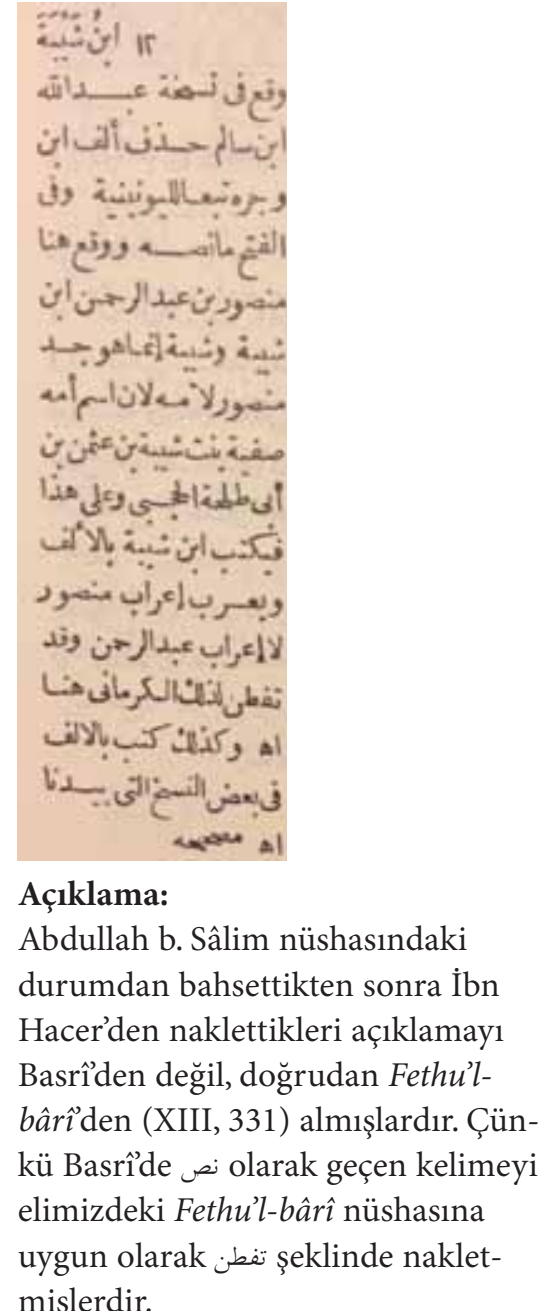 & $\begin{array}{l}\frac{1}{6} \\
\frac{5}{5} \\
\xi^{\circ} \\
2\end{array}$ \\
\hline
\end{tabular}

Basrînin, Yûnînînin kopyaları başlığı altında tanıttığımız Muhammed elMizzî kopyasından ve Münzirînin (ö. 656/1258) Buhârî nüshasından yaptığ1 nakiller de aynen yansitılmıştır. 
Örnek 6:

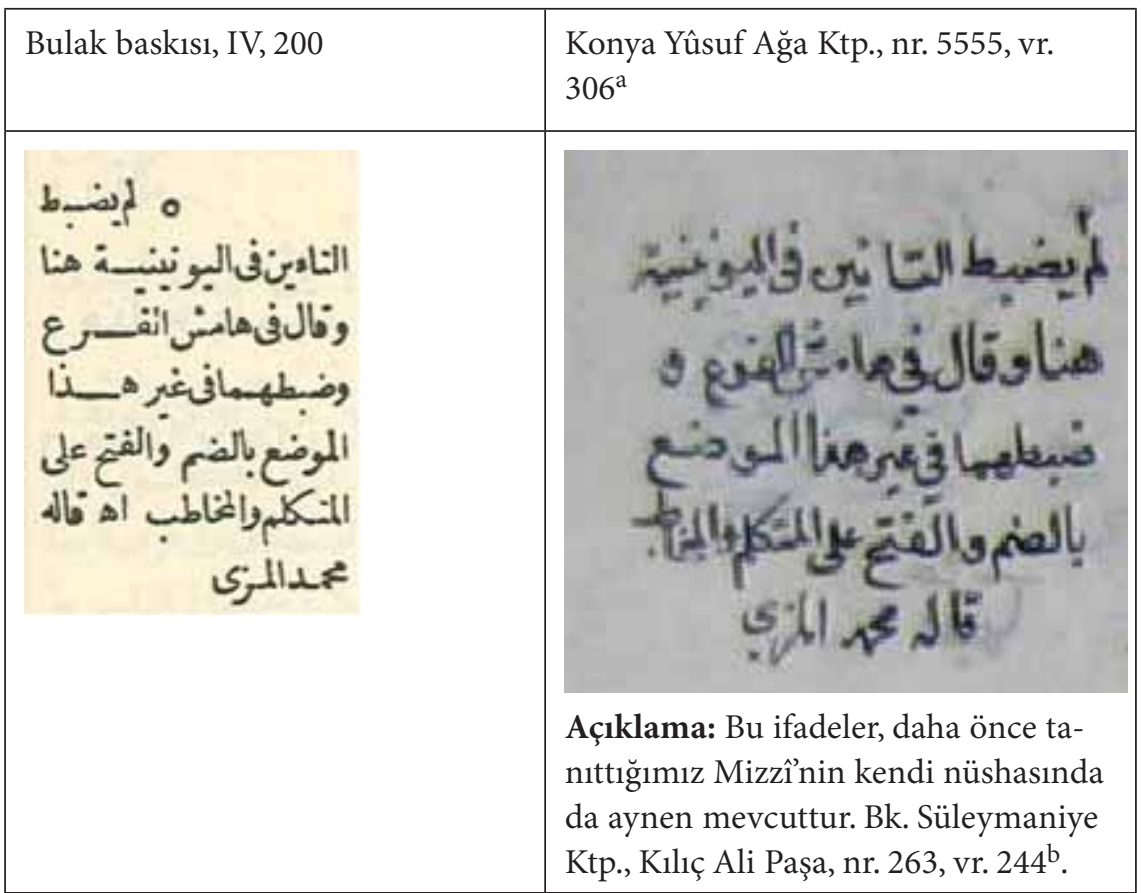

Örnek 7:

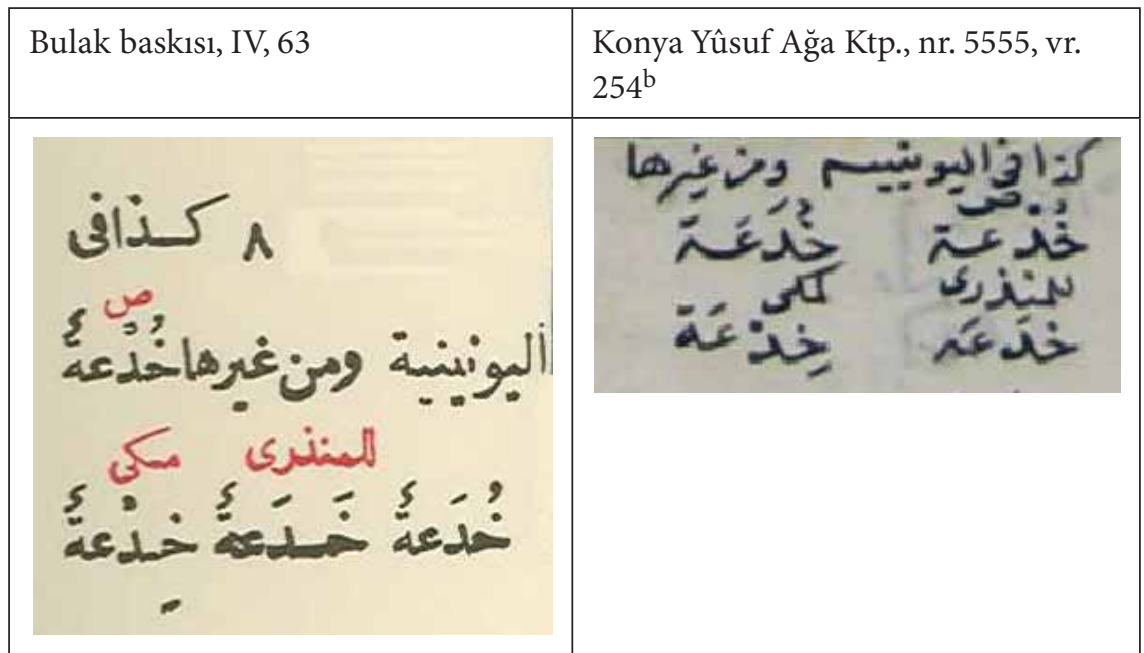

Ezherliler'in Basrî nüshasını yansıtmadıkları yerler de mevcuttur ve buralarda muhakkak bir açıklama yapmışlardır. 
Örnek 8:

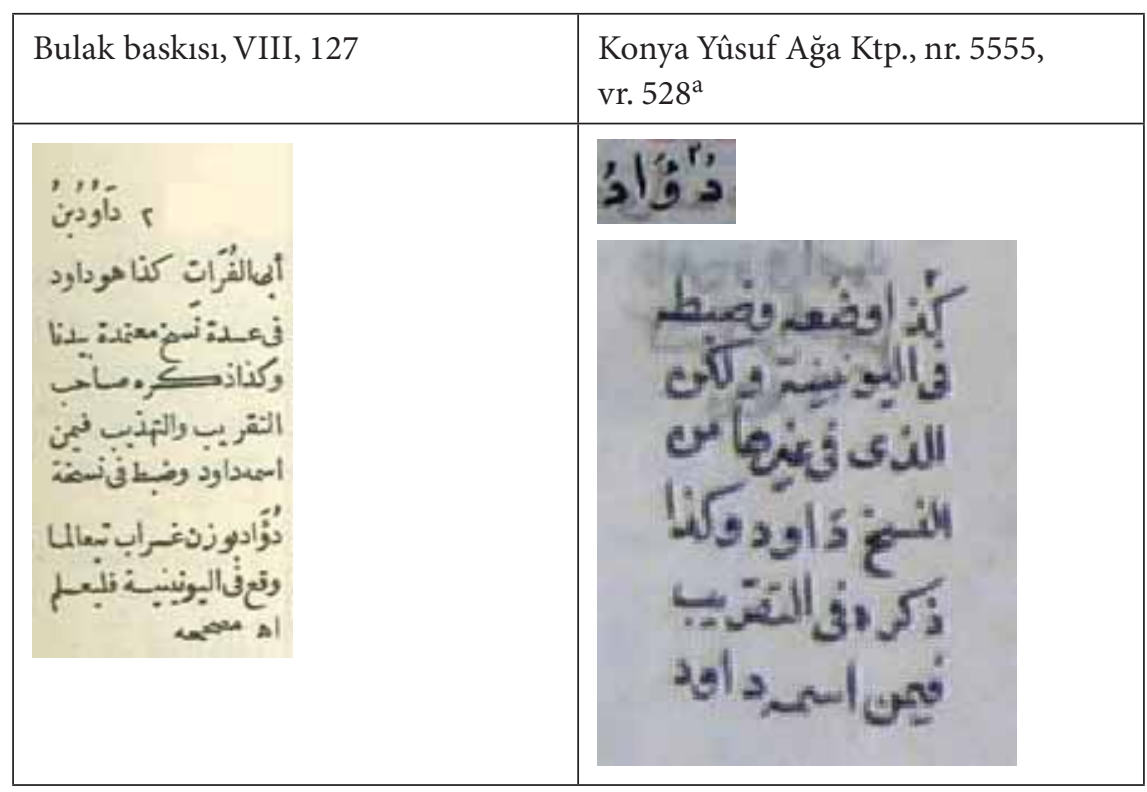

Örnek 9:

\begin{tabular}{|c|c|}
\hline Bulak baskısı, V, 164 & $\begin{array}{l}\text { Konya Yûsuf Ağa Ktp., nr. 5555, } \\
\text { vr. } 368^{\text {a }}\end{array}$ \\
\hline 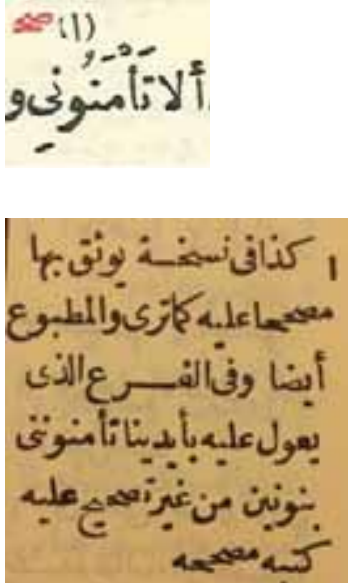 & 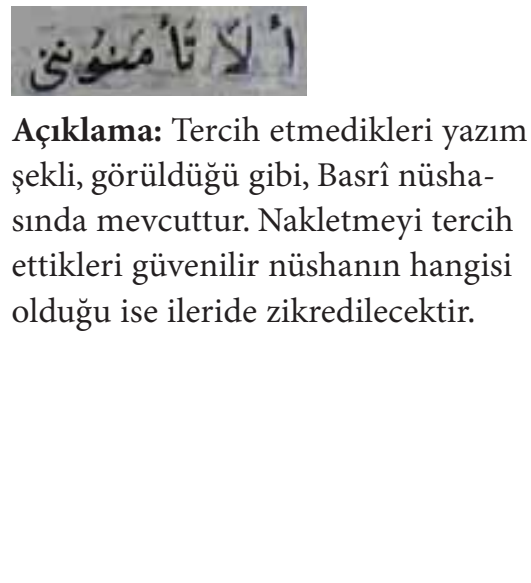 \\
\hline
\end{tabular}

Abdullah b. Sâlim'in asıl (Yûnîniyye) ile kopyalar (fer'ayn, el-fer'u'l-Mekkî vb.) arasında yaptığı karşılaştırmalar da aynen yansıtılmış ve alıntı olduğu çoğu zaman belirtilmemiştir. 
Örnek 10:

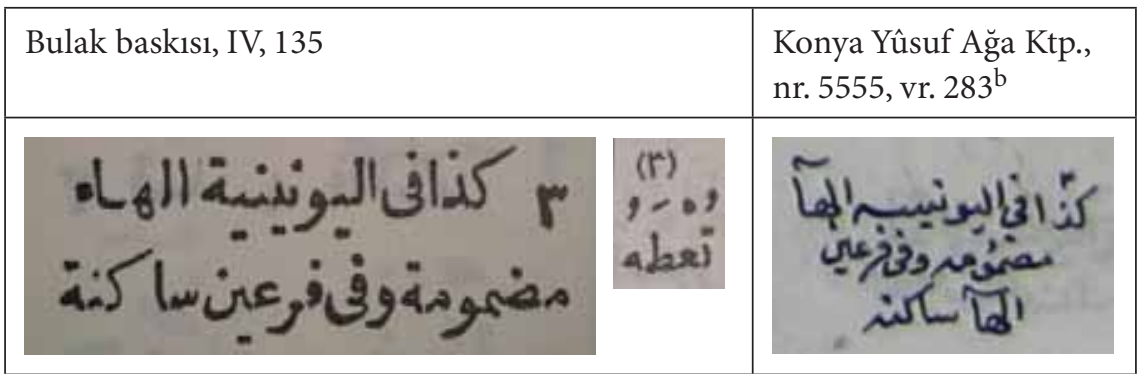

Örnek 11:

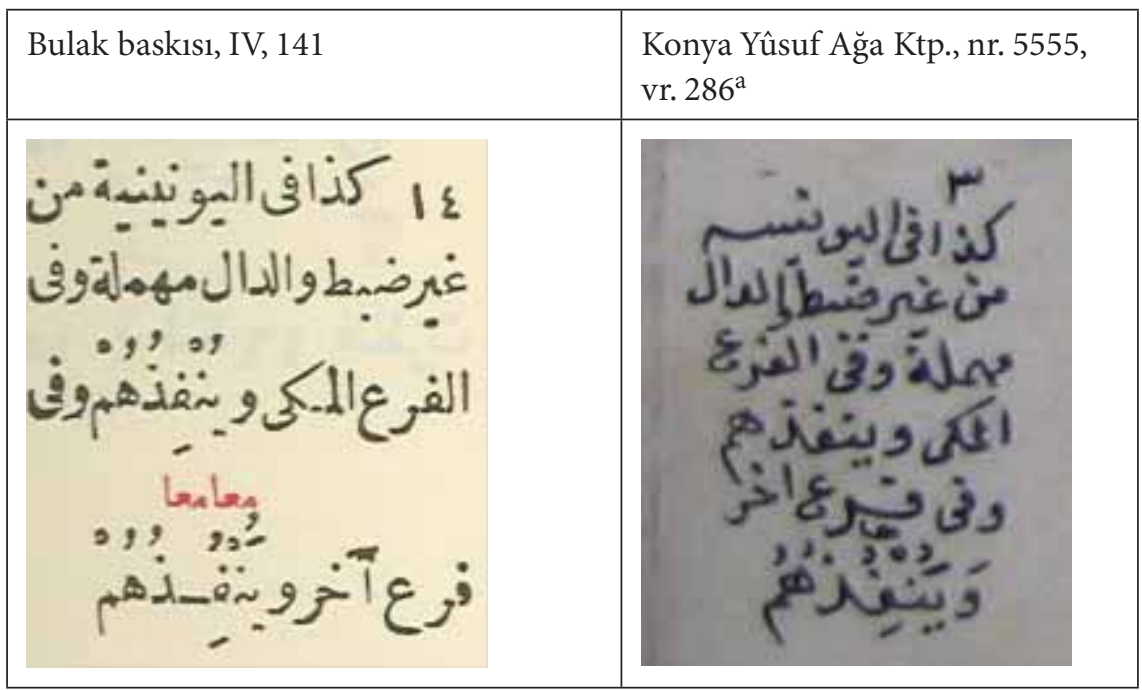

\section{Basrî Nüshasına Uymayan Yerler:}

Bulabildiğimiz Basrî nüshalarının birer kopya olduğunu belirtmiştik. Asıllarda olabileceği gibi, sağlam kopyalarda da bazı kusurların bulunması veya bir kopyanın asıldaki her şeyi yansıtamaması çok normaldir. Bu sebeple, Ezherliler'in Basrî nüshasından yaptıkları nakil ile elimizdeki Konya (Yûsuf Ağa) nüshasının uyumlu olmadığı yerler de mevcuttur. ${ }^{86}$ Elimizdeki diğer Basrî nüshalarından uyumlu olanı da ayrıca belirterek tespit edebildiğimiz örnekler şunlardır:

86 Bunun tam tersi de yani Konya nüshasının uyduğu ama diğer bazı Basrî nüshalarının uymadığı yerler de mevcuttur. 
Örnek 12:

\begin{tabular}{|c|c|c|}
\hline Bulak baskısı, IX, 153 & $\begin{array}{l}\text { Konya Yûsuf Ağa Ktp., } \\
\text { nr. 5555, vr. } 598^{\mathrm{b}}\end{array}$ & $\begin{array}{l}\text { Süleymaniye Ktp., } \\
\text { Fâtih, nr. 1053, vr. 616 }\end{array}$ \\
\hline 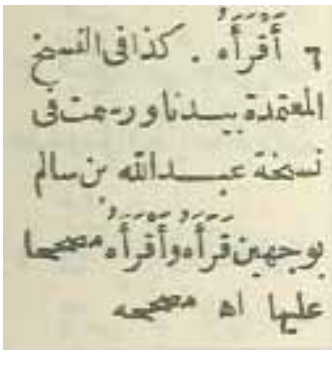 & $\begin{array}{l}\text { Açılama: Burada } \\
\text { "ekleme sonrasında } \\
\text { oluşan" tek vecih yansı- } \\
\text { tılmıştır. }\end{array}$ & $\begin{array}{l}\text { Açılama: İki vecih de } \\
\text { yansıtılmış ve sonradan } \\
\text { eklenen elif ile sükûn } \\
\text { kırmızıyla yazılmış, } \\
\text { üzerine de tashih işare- } \\
\text { ti konulmuştur. }\end{array}$ \\
\hline
\end{tabular}

Örnek 13:

\begin{tabular}{|c|c|c|}
\hline Bulak baskısı, IX, 152 & $\begin{array}{l}\text { Konya Yûsuf Ağa } \\
\text { Ktp., nr. 5555, vr. } \\
598^{\text {b }}\end{array}$ & $\begin{array}{l}\text { Süleymaniye Ktp., } \\
\text { Ayasofya, nr. } 778 \text {, } \\
\text { vr. } 631^{\text {b }}\end{array}$ \\
\hline 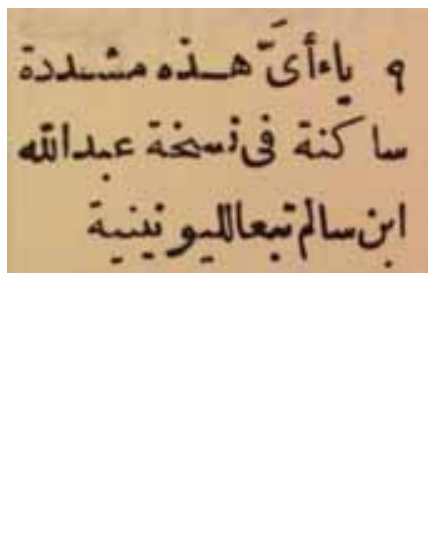 & $\begin{array}{l}\text { Açılama: Burada } \\
\text { büyük bir ihtimal- } \\
\text { le ana metindeki } \\
\text { sükûn, öncesinde } \\
\text { iki defa geçen aynı } \\
\text { kelimede olduğu } \\
\text { gibi, tenvin olarak } \\
\text { yorumlanmış gözük- } \\
\text { mektedir. }\end{array}$ & 密 \\
\hline
\end{tabular}

Örnek 14:

\begin{tabular}{|c|c|c|}
\hline Bulak Baskısı, 1/100 & $\begin{array}{l}\text { Konya Yûsuf Ağa Ktp., } \\
\text { nr. 5555, vr.38 }\end{array}$ & $\begin{array}{l}\text { Süleymaniye Ktp., } \\
\text { Fâtih, nr. } 1052 \text {, vr. } 69^{\mathrm{b}}\end{array}$ \\
\hline 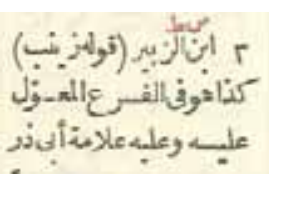 & $\begin{array}{l}\text { Açıklama: Burada Ebû } \\
\text { Zer işareti atlanmıştır. }\end{array}$ & \\
\hline
\end{tabular}




\section{Abdullah b. Sâlim'den Aktarılmayan Yerler:}

Ezher baskısında Basrînin bütün notları aktarılmamıștır. Bunların bir kısmı önemlidir; çünkü ya Yûnînînin kendi metniyle ilgili uyarılarını ya da anlaşılmayan bazı yerlerin izahını veya nüsha farklarına dair işareti içermektedir.

Örnek 15:

\begin{tabular}{|c|c|}
\hline Konya Yûsuf Ağa Ktp., nr. 5555, vr. 107ª & $\begin{array}{l}\text { Bulak baskısı, } \\
\text { II,92 }\end{array}$ \\
\hline 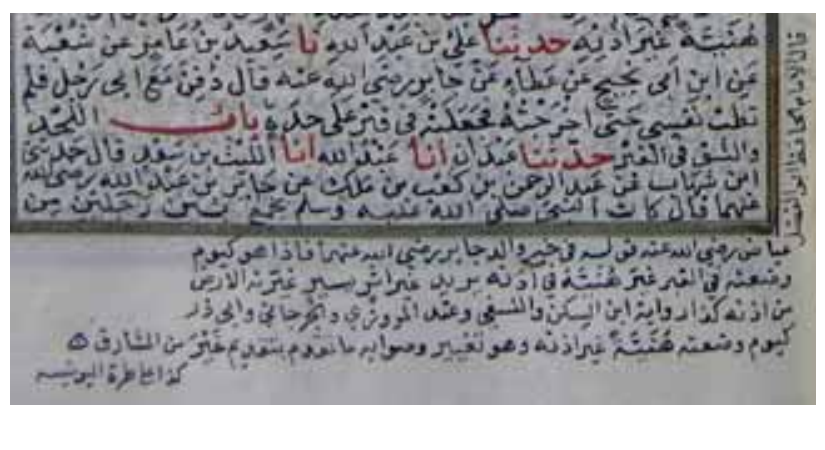 & $\begin{array}{l}\text { Açıklama: } \\
\text { Yûnînînin Kādî } \\
\text { İyâz'dan yaptığı } \\
\text { bu nakil, metin- } \\
\text { deki bir yanlışla } \\
\text { ilgili açılamayı } \\
\text { içermektedir; } \\
\text { ama Ezherliler } \\
\text { bunu nakletme- } \\
\text { mişlerdir. }\end{array}$ \\
\hline
\end{tabular}

Örnek 16:

Konya Yûsuf Ağa Ktp., nr. 5555, vr. 75a

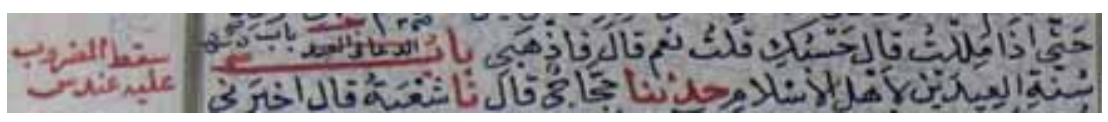

Bulak baskıs1, II, 16

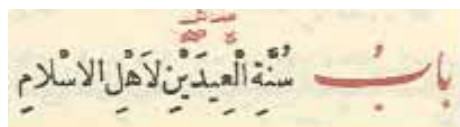

Açıklama: Üstü çizili ifade ve onunla ilgili açıklama nakledilmemiştir. 
Örnek 17:

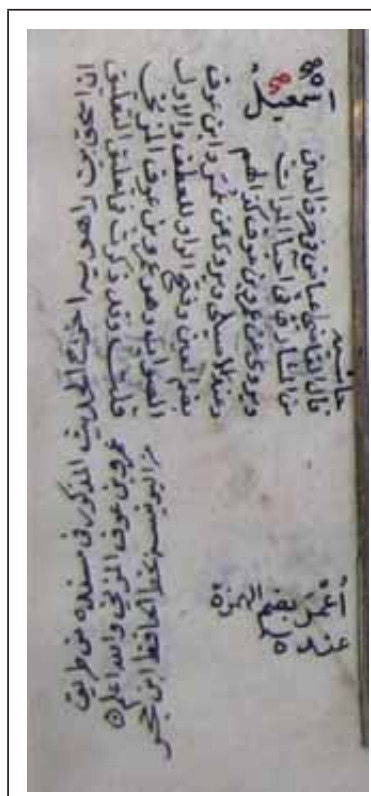

Açıklama: Bulak baskısında aktarılmayan bu bilgi sayesinde İbn Hacer'in Yûnînî nüshasının aslını okuduğunu ve bazı değerlendirmeler ilâve ettiğini öğrenmekteyiz.

Örnek 18:

Konya Yûsuf Ağa Ktp., nr. 5555, vr. 590a

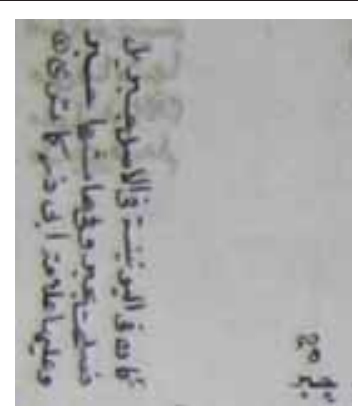

Açıklama: Bulak baskısında (IX, 134) aktarılmayan bu notta metinde حبر geçtiği halde kenarda da جبر yazıp üzerine Ebû Zer işareti konulması gibi bir garipliğin izahı Basrî tarafından yapılmaktadır. Asıl metin جبريل iken sonradan kelimesine dönüştürülmüş, böylece kenarda nüsha farklılığını yansıtan hâmiş boşa çıkmıştır. 


\subsection{Bedrânî Nüshası}

Daha önce tanıttığımız Bedrânî nüshasını Ezherliler'in, özellikle İbn Ebû Râfi' (İbn Râfi') nüshasını yansıtırken kullandıkları kesindir. Bedrânî kopyalarıyla karşılaştırarak, genellikle cümle düşüklükleri ve kelime eksikliklerini telafi eden notlar şeklindeki bu nakiller aşağıda yer almaktadır.

Örnek 19:

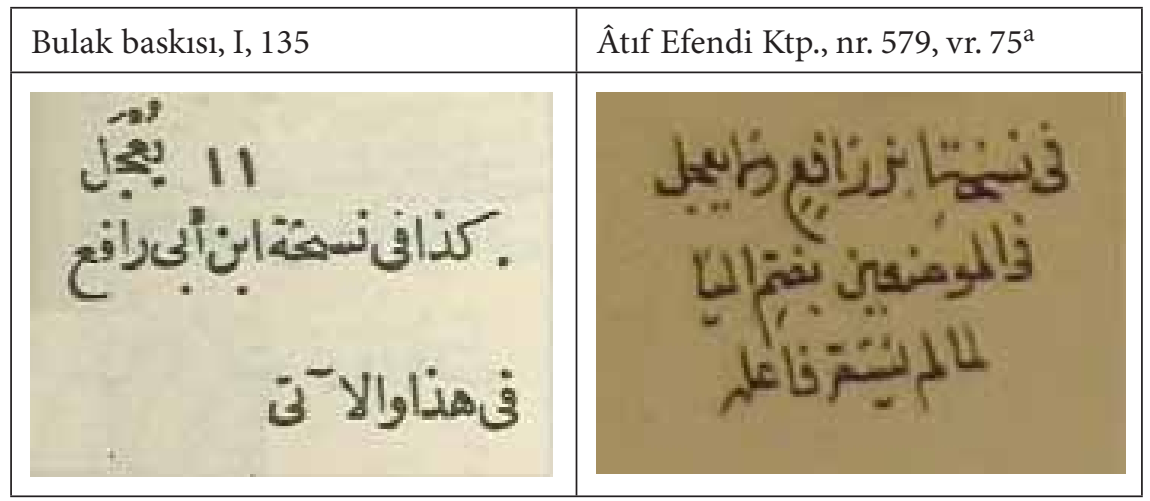

Örnek 20:

\begin{tabular}{|c|c|}
\hline Bulak baskısı, III, 6 & $\begin{array}{l}\text { Süleymaniye Ktp., Yazma Bağışlar, nr. 1557, vr. } \\
317^{\mathrm{a}}\end{array}$ \\
\hline 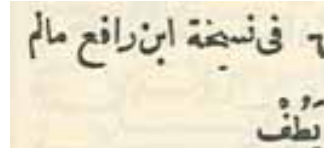 & ل \\
\hline
\end{tabular}

Ezherliler'in muteber bir nüshadan veya kopyadan diyerek aktardıkları notlar da bazan Bedrânî nüshasıyla uyuşmaktadır: 
Örnek 21:

\begin{tabular}{|c|c|c|}
\hline Bulak baskısı, II, 27 & $\begin{array}{l}\text { Konya Yûsuf } \\
\text { Ağa Ktp., nr. } \\
5555 \text {, vr. } 79^{\mathrm{a}}\end{array}$ & $\begin{array}{l}\text { Âtıf Efendi Ktp., } \\
\text { nr. } 579, \text { vr. } 106^{\mathrm{b}}\end{array}$ \\
\hline $\begin{array}{l}\text { Açıklama: İkinci hâmişi aldıkları mu- } \\
\text { teber nüshanın Bedrânîn nüshası olduğu } \\
\text { yandaki nakillerden anlaşılmaktadır. }\end{array}$ & $\begin{array}{l}\text { Líbi } \\
\text { Açılklama: } \\
\text { Basrîn nüsha- } \\
\text { sinda sadece } \\
\text { tek hâmiş } \\
\text { vardır. }\end{array}$ & 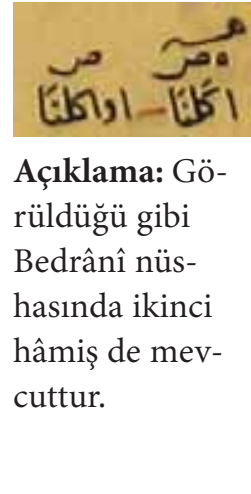 \\
\hline
\end{tabular}

Örnek 22:

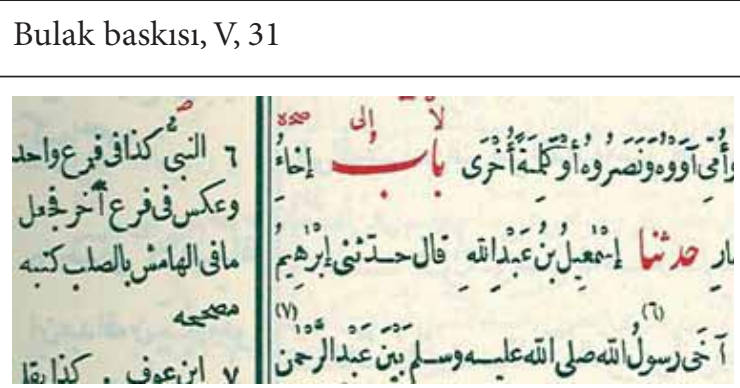

Açıklama: İsim vermeden iki fer' arasındaki farkı anlatmaktadırlar. Ama hâmişte النبي kelimesinin üzerine şüpheyi ifade eden tadbîb işareti koymakla yanılmışlardır. Diğer nüshalarda görüldügüü üzere bu işaret Hammevînin sembolü olan hâ harfidir.

Konya Yûsuf Ağa Ktp., nr. 5555, vr. $318^{\mathrm{b}}$

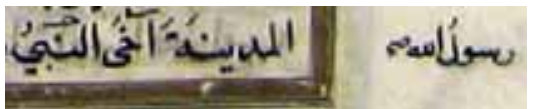

Açıklama: Ezherliler' in belirttiği gibi tam tersidir.

Âtıf Efendi Ktp., nr. 579, vr. $405^{\mathrm{a}}$

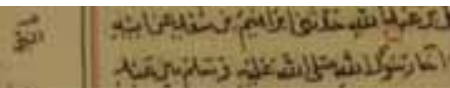

Açıklama: Ezherliler'in tercih ettiği nüsha budur. 


\subsection{Muhammed el-Mizzî Nüshası}

Yûnînînin kopyaları kısmında bahsettiğimiz ve Tenkiziyye denilen yere vakfedildiği için el-fer'u't-Tenkiziyye diye anılan bu nüshanın Ezherliler taraوفي .الفرع التنكزي فأُلْفيَها بالفاء ونصب الياء وعليها علامة أبي ذر مصححا عليها

Türkiye'de mevcut olan Mizzî nüshasında, üzerindeki "kırmızı mürekkeple Ebû Zer işareti ve tashih kaydı" dahil

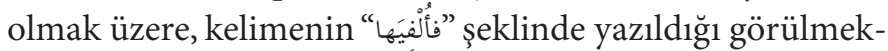
tedir. $^{88}$

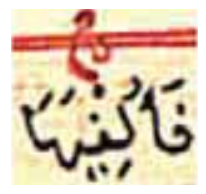

Ezherliler, وغكذا في نسخة عبد الله بن سالم ونسخة المزي (Bulak baskıs1, IX, 11) diyerek ifade ettikleri89 bir örnekte de metnin "أو أمة فشهرeklinde olduğunu belirtmektedirler. Elimizdeki Mizzî nüshasında

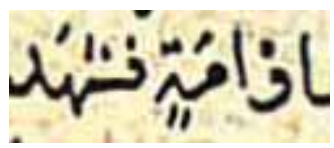
da aynen bu şekildedir. ${ }^{90}$

Yukarıdaki ifadeler Ezherliler'in bu nüshayı gördüklerini göstermektedir. Ama Kastallânînin çokça övdüğü ve şerhinde kullandığı bu nüshayı niçin yoğun olarak kullanmadıkları anlaşılmamaktadır. Şu an Mısır'daki nüshada olduğu gibi onların elindeki nüshanın da eksik olması ya da Türkiye'deki nüsha gibi Yûnînî kopyası olmayan nüshaları da içeriyor olması bunda etkili olmuş olabilir.

\subsection{Muhammed b. İlyâs Nüshası}

Yukarıda Yûnînî kopyalarını sıralarken ismini zikrettiğimiz Muhammed b. İlyâs’’n, nüshasını mukabele ettiği nüshalardan birinin de Mizzînin ve Zehebî̀nin tashih ettiği nüsha olduğunu zikretmiştik. Dolayısıyla Mizzî ve Zehebînin konuyla ilgili mülâhazaları Muhammed b. İlyâs’n nüshas1na da yansımıștır. Buna binaen Ezherliler'in "Hâfız Mizzî nüshası" derken kastettikleri nüshanın bu olduğunu düşünüyoruz. ${ }^{91}$ Kahire'de bulunan bu

87 Buhârî, el-Câmiu's-sahîh (Bulak), III, 125.

88 Süleymaniye Ktp., Kılıç Ali Paşa, nr. 263, vr. 158 ${ }^{\mathrm{b}}$. Türkiye'deki bu nüsha Tabnâvînin (Ali b. Muhammed b. Ahmed el-Heysemî) yazdığı bir kopyadır. Birmâvînin (ö. 831/1428) talebesi olan bu şahıs, Yûnînî rumuzları yanında Dimyâtî (ö. 705) nüshasını ve başka bir nüshayı da rumuzlarla göstermiş, böylece nüshası biraz daha karışık bir hal almıştır.

89 Ezherliler "nüshatü’l-Mizzî" ifadesiyle bu nüshayı kastederken, ileride geleceği gibi "nüshatü'l-Hâfız el-Mizzî” ve "Aslün sahhahahu'z-Zehebî ve'l-Mizzî” ifadeleriyle başka nüshaları kastetmektedirler.

90 Süleymaniye Ktp., Kılıç Ali Paşa, nr. 263, vr. 479.

91 كذا في القسطلاني ونسخة الحافظ المزي وفي نسخة عبد الله بن سالم Bk... Buhârî, el-Câmiu’s-sahîh (Bulak), IX, 57. Yûnînînin talebesi olan Hâfız Yûsuf el-Mizzînin kendisine ait bir 
nüshaya ${ }^{92}$ henüz ulaşamadığımızdan bu bölümde herhangi bir karşılaştırma yapamıyoruz. Nüshayı bizzat inceleyen Menûnînin belirttiğine göre bu nüsha Ezherliler tarafından kullanılmıştır. ${ }^{93}$

\section{Takıyyüddin es-Sübkî Nüshası}

Meşhur âlim Ali es-Sübkî (683-756) nüshası da bir Yûnînî kopyası değildir. Ama o da hocası Dimyâtînnin (613-705) Ebü'l-Vakt nüshası ${ }^{94}$ ile Ebû Mektûm b. Ebû Zer rivayeti olan Ebû Zer nüshası arasındaki farkları göstermiştir. Zehebî ile Mizzînin tashihini içerdiğinden ${ }^{95}$ ayrıca dikkate alınması gereken bu nüsha Türkiye'de mevcuttur. ${ }^{96}$ Ezherliler bu nüshadan bahsederken "صلٌ صحّحه المزّي والذهبي "ifadesini kullanmaktadırlar. Aşağıda Ezherliler’in bu nüshayla ilgili ifadelerinin, elimizdeki Sübkî nüshasıyla karşılaştırması yapilacaktır.

\section{Örnek 23:}

Ezherliler kullandıkları rumuzlarla ilgili daha önce yaptıkları bir açıklamayı düzeltirlerken VII. cildin en başında bu nüshadan da bahsetmekte-

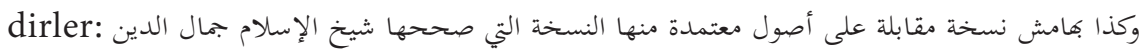

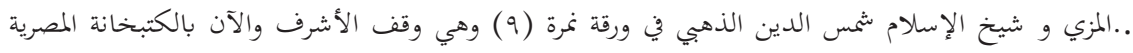

Burada Yûnînî nüshasında bulunan "Ş" harfinin daha önce Kābisî olabileceğini söylediklerini ama Kastallânîde ve söz konusu nüshada bu harfin Ebü’l-Vakt'e işaret ettiği açıklamasının bulunduğunu belirtmektedirler. ${ }^{97}$ Yanda görüldüğü üzere

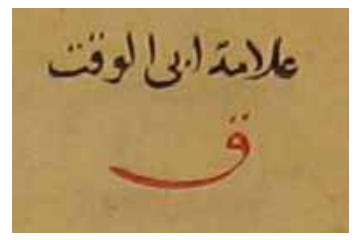
elimizdeki nüshanın rumuzla ilgili izahı aynen naklettikleri gibidir.

Yûnînî nüshanın varlığı bilinmemektedir. Zaten müstakil bir nüshası olup da bunun bilinmemesi veya konuyla ilgili çalışma yapanların böylesi önemli bir nüshadan haberdar olmamaları garip bir durum ortaya çıkarırdı.

92 Dârü'l-kütübi'l-Misriyye, nr. 1108-1109.

93 Menûnî, “Sahîhu'l-Buhârî fi'd-dirâsâti'l-magribiyye”, s. 533.

94 Dimyâtînin kendisi için yazdığ 1 ve tashih ettiği bir nüsha olduğundan, önemlidir. İbnü’l-Mulakkın’ın Buhârî şerhinde kullandığı nüshanın Dimyâtî nüshası olma ihtimali vardır. Bk. et-Tavzîh, X, 549 (müstensihin notu).

95 Bir önceki nüsha ile aynı olmadığı birazdan vereceğimiz örneklerden anlaşılacaktır.

96 Nuruosmaniye Ktp., nr. 703.

97 Yûnînîdeki "Ş” harfinin Ebül-Vakt'e veya Kābisî̀ye işaret ettiğine dair herhangi bir delil yoktur. 
Örnek 24:

Ezherliler bir hâmişte, âyetteki الرَّشيد kelimesiyle ilgili olarak bunun hangi nüshada bulunup bulunmadığ 1 açıklamasını yaparken bu nüshadan da bahsetmektedirler: كذا في هامش اليونينية لفظ 》الرشيد) محكوكًا. وكذا ليس في أصل مصحَّح على كَّu ibare, Basrî nüshasında olduğu gibi, elimizdeki Sübkî nüshasında da kenarda mevcuttur. ${ }^{99}$

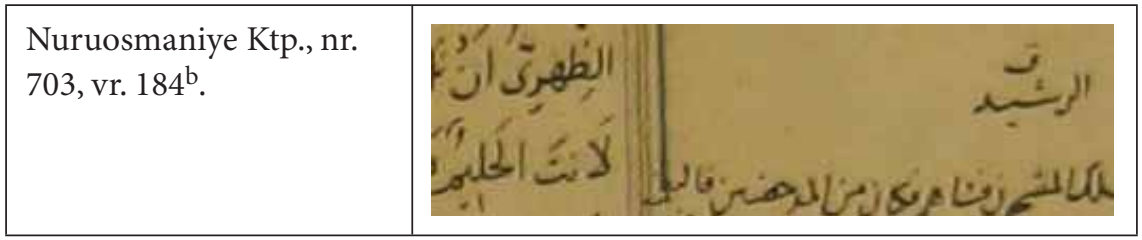

Ezherliler bazan isim vermeden de bu nüshadan alıntı yapmaktadırlar:

Metinde geçen ألأمنوني ifadesi için "Güvenilir bir nüshada tashih kayıtlı olarak bu şekildedir" demektedirler. ${ }^{100}$ Sübkî nüshasında da aynen belirttikleri gibidir. ${ }^{101}$ Daha önce naklettiğimiz gibi, Basrî nüshasında ve diğerlerinde ise iki nûn ile yazılmıştır. ${ }^{102}$

Diğer bir hâmişte ise ${ }^{103}$ metinde geçmeyen عُ إنمَ lafzının iki önemli nüshada geçtiğini belirtmektedirler. Elimizdeki yazma nüshalara göre bunların biri Bedrânî nüshası ${ }^{104}$ diğgeri de bahsettiğimiz Sübkî nüshasıdır. ${ }^{105}$ Basrî̀de geçmeyen bu kelime (Konya Yûsuf Ağa Ktp., nr. 5555, vr. 277ª), olmas1 muhtemel Bikāî nüshasında da yoktur (Köprülü Ktp., Fâzıl Ahmed Paşa, nr. 355 , vr. $\left.128^{\mathrm{b}}\right)$.

Daha önce geçen nüshada değindiğimiz gibi nüshatü'l-Hâfız el-Mizzî dedikleri nüsha farklı olduğundan, bu isimle aktardıkları bilgiler Sübkî nüshasıyla uyuşmamaktadır. Meselâ فِ فِلَ عِلِّيَّ ifadesinin Kastallânî ve Hâfız Mizzî nüshasında ayın harfinin zammeli ve kesreli olduğunu belirtmekte, Basrî

98 Buhârî, el-Câmiu's-sahîh (Bulak), IV, 159.

99 Bedrânî nüshasında (Âtıf Efendi Ktp., nr. 579, vr. $365^{\text {a }}$ ) ve Yûnînî kopyalarının sonunda tanıttığımız Bikāî nüshasında (Köprülü Ktp., Fâzıl Ahmed Paşa, nr. 355, vr. 125흐) bu kelime metinde geçmektedir.

100 Buhârî, el-Câmiu’s-sahîh (Bulak), V, 164.

101 Nuruosmaniye Ktp., nr. 703, vr. $237^{\mathrm{b}}$.

102 Konya Yûsuf Ağa Ktp., nr. 5555, vr. 368 (Basrî nüshas1); Âtıf Efendi Ktp., nr. 580, vr. $68^{\text {b }}$

(Bedrânî nüshası); Süleymaniye Ktp., Kılıç Ali Paşa, nr. 263, vr. 298ª (Mizzî nüshası).

103 Buhârî, el-Câmiu's-sahîh (Bulak), IV, 117.

104 Âtıf Efendi Ktp., nr. 579, vr. $344^{\mathrm{b}}$.

105 Nuruosmaniye Ktp., nr. 703, vr. $174^{\text {b }}$. 
nüshasında ise ظelimesinin tenvinli olduğunu eklemektedirler. ${ }^{106}$ Konumuz olan Sübkî nüshasında ayın harfinde sadece zamme işareti vardır. ${ }^{107}$

Ezherliler'in daha önce bahsettiğimiz ve Yûnînî nüshasının kopyasının kopyası (فرع الفرع) olan Bikāî (ö. 806) nüshasını kullanma ihtimalleri de yüksektir. Fakat biz bu hususta henüz kesin delil tespit edebilmiş değiliz.

Ezherliler'in bunlardan başka nüshalar kullandıkları da kesindir. Çünkü bu çalışmada zikredilen nüshaların hiçbirisinde bulunmayan nüsha bilgileri de nakletmektedirler.

\section{Değerlendirme}

Buhârînin el-Câmiu's-sahîh adlı eserinin çeşitli nüshaları arasında mevcut olan farkları tek nüshada yansıtma işi Asîlî (ö. 392/1002) ve Ebû Zer (ö. 434/1043) dönemine kadar uzanmaktadır. Daha fazla nüshayı içeren çalışmaların ise ilkini Sagānî (ö. 650/1252), en meşhurunu Yûnînî (ö. 701/1302), en sonuncusu ve kapsamlısını da Sehârenpûrî (ö. 1297/1880) yapmıştır.

Sultan II. Abdülhamid'in emriyle Bulak Emîriyye Matbaası'nda gerçekleştirilen baskıda da çok meşhur olması sebebiyle Yûnînî nüshası kullanılmıştır. el-Câmi'u's-sahîh'in "Sultâniye baskısı" diye bilinen ve Ezherli âlimlerin nezaretinde yapılan bu baskıda, neşre esas kabul edilen yazma nüshalar yönüyle muğlak ve cevapsız bırakılan birtakım hususlar mevcuttur. Bu belirsizlikleri gidermeyi amaçlayan bu çalışmada Türkiye'deki yazma eser birikiminin Buhârî nüshalarını ilgilendiren yönünün oldukça zengin olması sayesinde birçok yeni bilgiye ve sonuca ulaşılmıştır.

Eseri baskıya hazırlayanların hangi yazma nüshaları kullandıklarına dair bir beyanda bulunmamış olmaları ve esere yazdıkları mukaddimede net olmayan ibarelerle konuyu geçiştirmiş olmaları, bizi metnin kenarında yapılan izahlara yönlendirmiş ve ancak buradan yapılan çıkarımlar neticesinde sağlıklı sonuçlara erişebilmek mümkün olmuştur.

İstanbul'dan gönderilen nüshanın mahiyeti ve bu nüshanın baskıda kullanıldıktan sonraki âkıbeti meselesi, konunun belki de en çok cevap bekleyen vechesidir. Eserin herhangi bir yerinde Yûnînînin asıl nüshasının kullanıldığına dair sarih bir beyan bulunmamaktadır. Sadece dönemin Ezher şeyhi Hasûne en-Nevâvînin esere yazdığ takrirde kendilerine emirnâme eşliğinde

106 Buhârî, el-Câmiu's-sahîh (Bulak), IX, 57. Basrî̀de aynen belirttikleri gibidir (Konya

Yûsuf Ağa Ktp., nr. 5555, vr. 564ª).

107 Nuruosmaniye Ktp., nr. 703, vr. $393^{\mathrm{b}}$. 
İstanbul'dan bir Yûnînî nüshası gönderildiğini ifade etmiş olması, konuyla ilgili genel kanaatin Yûnînîye ait asıl nüshanın gönderildiği yönünde şekillenmesine zemin hazırlamıștır. Oysa bu ibareden, asıl nüsha sonucu elde edilebileceği gibi asıl nüshadan istinsah edilmiş fer" nüsha sonucunu elde etmek de mümkündür.

Eserde Yûnînînin asıl nüshasının kullanıldığı izlenimini veren açıklamaların peşine düşüldügüunde ise, yapılan nüsha taramaları neticesinde eriştiğimiz Abdullah b. Sâlim el-Basrî nüshasının da aynı açıklamaları Abdullah b. Sâlim'in dilinden içeriyor olması Yûnînînin aslını kullananların musahhihler değil Abdullah b. Sâlim olduğunu ortaya koymuştur. Osmanlı arşiv vesikaları arasında bulunan emirnâme tetkik edildiğinde de aynı sonuca ulaşmak mümkündür. Zira gönderilen nüsha "nüsha-i asliyyenin esah rivayeti" denilmek suretiyle tasvir edilmektedir. Bu durum Nevâvînin yazısından birkaç sayfa sonra gelen mukaddimede, tashihe esas kabul edilen nüshanın "gayet sahih ve net bir Yûnînî kopyası" olduğu ifade edilerek de dile getirilmiştir.

Ulaştığımız sonucu teyit eden bir başka durum ise Kettânînin 1920’li yıllarda Mekke'de karşılaştığı Şeyh Tâhir Sümbül Efendi’nin elinde Abdullah b. Sâlim nüshasını gördügünü ve Tâhir Sümbül'ün daha önce Bulak baskısında kullanılmak üzere bu nüshayı İstanbul’a götürdügünü söylediğini nakletmesidir.

Bütün bunlar İstanbul'dan gönderilen nüshanın Yûnînînin asıl nüshası olmadığını ve dolayısıyla basım esnasında Ezherliler'in elinde Yûnînî aslının olmadığını açık bir şekilde ortaya koymaktadır. Ayrıca yapılan mukayeseler neticesinde Yûnînînin açılamalarına ilâveten eserde yoğun bir şekilde yer alan Yûnînînin aslı ve kopyaları arasındaki karşılaştırmalar ve İbn Hacer ile Kastallânîden yapılan çok sayıda alıntılar Abdullah b. Sâlim nüshasındakilerle birebir benzerlik gösterdiğinden bu durum baskıya esas kabul edilen nüshanın Abdullah b. Sâlim el-Basrî nüshası olduğunu netleştirmektedir. Ancak Ezherliler'in Basrî̀den almadıkları yerler olabildiği gibi Basrî nüshasına uymayan yerlerin de mevcut olduğu yine bu mukayeseler neticesinde ortaya çıkan bir başka sonuçtur.

Ezherliler'in Basrî nüshası dışında da nüshalar kullandıkları tespit edilmiştir. Bir kısmı ilk defa bu çalışmada dile getirilen tespitler olmak üzere Muhammed el-Mizzî, Muhammed b. İlyâs, Muhammed b. Hasan el-Bedrânî ve Takıyyüddin es-Sübkî̀ye ait nüshaların da kullanıldığı, örnekleriyle birlikte sunulmaktadır.

Yûnînî benzeri çalışmalar olan ve İslâm dünyasında neredeyse hiç bilinmeyen Sagānî ve Sehârenpûrî̀ye ait nüshaları da bir nebze tanıttığımız bu 
çalışma sayesinde bir defa daha ortaya çımıştır ki Türkiye'de tahminlerimizin çok ötesinde zengin bir yazma eser külliyatı mevcuttur. Ne var ki üzerinde en fazla emek sarfedilmiş eserler olması beklenilen Buhârî nüshaları bile gerektiği gibi tasnif edilmemiş ve yeterince tanıtılmamıştır.

$\mathrm{Bu}$ çalışmada mukayeseli olarak künye bilgilerini verdiğimiz yazma nüshaların bir kısmı araştırmacıların elinde olmasına rağmen mahiyeti ve önemi farkedilememiş, büyük bir kısmı ise hiç bilinmemiştir. Konuyla ilgili yeni çalışmalara vesile olabileceğini düşündüğümüz bu makalenin, yazma eserlerle ilgili tasnif ve tanıtım çalışmalarının hızlandırılmasına da katkıda bulunmasını ümit ederiz.

\section{Bibliyografya}

Abdülhalîm, Cuma Fethî, Rivâyâtü'l-Câmiìs-sahîh ve nüsahuhû, I-II, Katar: Dâru'l-felâh, 1434/2013.

Albayrak, Ali, "Sahîh-i Buhârînin Tashihi”" (yayımlanmamış çalışma).

Altuntaş, M. Celil, “Osmanlı İlim Geleneğinde Buhârîhânlık” (yüksek lisans tezi), Selçuk Üniversitesi Sosyal Bilimler Enstitüsü, Konya, 2010).

Aydın, Arafat, "Sagânînin Sahîh-i Buhârî Nüshası ve Türkiye Kütüphanelerindeki Yazmaları" (uzmanlık tezi), Türkiye Yazma Eserler Kurumu Başkanlığı, İstanbul 2016.

Basrî, Abdullah b. Sâlim, Zıyâüs-sârî fî mesâliki Sahîhi'l-Buhârî, haz. Nûreddin Tâlib, I-XVIII, Katar: er-Rakīm li'l-buhûs ve’d-dirâsât, 1432/2011.

Buhârî, el-Câmiu's-sahîh, I-IX, Bulak: el-Matbaatü'l-kübrâ el-emîriyye, 1311-13.

,el-Câmiu's-sahîh bi-hâşsiyetil-muhaddis es-Sehârenfûrî, I-XV, haz. Takıyyüddin en-Nedvî, I-XV, Beyrut: Dârü’l-beşâiri'l-İslâmiyye, 1432/2011.

el-Câmiu's-sahîh, haz. M. Mustafa el-A'zamî, Riyad: Dârü'l-A'zamî, $1434 / 2013$.

,el-Câmiu's-sahîh, haz. Merkezü'l-Buhûs ve takniyyetü'l-ma'lûmât, I-X, Kahire: Dârü’t-te’sîl, 2012.

,el-Câmiu's-sahîh, I-IX, Dâru'l-cîl, Beyrut, t.y.

Fâsî, Takıyüddin, Zeylü't-Takyîd, haz. Kemâl Yûsuf el-Hût, I-II, Beyrut: Dârü'lkütübi'l-ilmiyye, 1410/1990. 
İbn Hacer el-Askalânî, Fethu'l-bârî, I-XIII, Beyrut: Dâru'l-ma'rife, 1379. İnbäül-gumr bi-enbâi'l-umr, haz. Hasan Habeşî̀, I-III, Kahire: Lecnetü İhyâi't-türâsi'l-İslâmî, 1389-92/1969-72.

İbnü'l-Mulakkın, et-Tavzîh li-şerhi'l-Câmiiłs-sahîh, haz. Nûreddin Tâlib, I-XXXVI, Katar : Dâru'l-felâh, 2012.

Kādî İyâz, el-İlmâ' ilâ ma'rifeti usûlìr-rivâye, haz. Seyyid Ahmed Sakr, Kahire: Dârü’t-türâs, 1389/1970.

Kandemir, M. Yaşar, “İbn Râfi'”, TDV İslâm Ansiklopedisi (DİA), XX, 239.

Kastallânî, Ahmed b. Muhammed, İrşâdü̉s-sârî, I-X, Beyrut: y.y., 1323.

Kettânî, M. Abdülhay, Fihrisül-fehâris, haz. İhsan Abbas, I-III, Beyrut: Dârü'lgarbi'l-İslâmî, 1402/1982.

Kızıl, Fatma, "Yûnînî”, DİA, XLIII, 595-96.

Menûnî, Muhammed, "Sahîhu'l-Buhârî fíd-dirâsâti'l-magribiyye min hilâli ruvâtihi'l-evvelîn ve rivâyâtihî ve usûlih", Mecelletü'l-Mecmai'l-lugatilArabiyye bi-Dımaşk, 4/3 (1394): 500-49.

Mizzî, Tehzîbü'l-Kemâl, haz. Beşşâr Avvâd Ma'rûf, I-XXXV, Beyrut: Müessesetürr-risâle, 1400/1980.

Özşenel, Mehmet, Pakistan'da Hadis Çalışmaları, İstanbul: Marmara Üniversitesi İlâhiyat Fakültesi Vakfı, 2014.

Quiring-Zoche, Rosemarie, "How al-Buhari's Sahih Was Edited in the Middle Ages: 'Ali al-Yunini and His Rumuz," Bulletin d'Studes Orientales, 50 (1998): 191-222.

Rûdânî, Silatü'l-halef bi-mevsûliss-selef, haz. Muhammed Haccî, Beyrut: Dârü'lgarbi'l-İslâmî, 1408/1988.

Safedî, A'yânü'l-asr, haz. Ali Ebû Zeyd v.dğr., I-VI, Beyrut: Dârü’l-fikri'lmuâsır, 1418.

Sellûm, Ahmed b. Fâris, "Nüshatü'l-İmâm es-Sagānî min Sahîhi'l-Buhârî ve kıymetühü'l-ilmiyye”, Mecelletül-Cündî el-müslim, 39 (1431/2010): 8-16.

Sezgin, Fuat, Buhârînin Kaynaklarl, Ankara: Kitâbiyât, 2000.

Süyûtî, Hüsnü̉l-muhâdara fî târîhi Mısr ve'l-Kāhire, haz. M. Ebü'l-Fazl İbrâhim, I-II, Kahire: Dâru ihyâi'l-kütübi'l-Arabiyye, 1387/1967.

Woll, John Obert, “Abdullah b. Sâlim el-Basrî ve 18. Yüzyılda Hadis İlmi”, çev. Nail Okuyucu, Batı Gözüyle Tecdid 1700-1850: İslâm Dünyasında Tecdid Hareketleri, ed. Nail Okuyucu, İstanbul: Klasik, 2014, s. 217-30. 
Zehebî, Siyeru a 'lâminn-nübelâ', I-XXV, Beyrut, Müessesetü’r-risâle, 1405/1985.

Ziriklî, el-A 'lâm, haz. Züheyr Fethullah, I-VIII, Beyrut: Dârü'l-ilm li’l-Melâyin, 1986.

\section{Kullanılan Yazma Nüshalar}

Amasya Beyazit Yazma Eser Ktp., No. 199.

Âtıf Efendi Yazma Eser Ktp., No. 579, 580.

Başbakanlık Osmanlı Arşivi, Y. PRK. MK. 6/89.

Beyazıt Yazma Eser Ktp., Veliyyüddin Efendi, No. 501.

Bursa İnebey Ktp., Ulucami, No. 539-543.

Dâru'l-Kütübi'l-Mısriyye, No. 177, 1108, 1109.

Edirne Selimiye Ktp., No. 1042.

Konya Bölge Yazma Eser Ktp., No. 4772, 8980

Konya Yûsuf Ağa Ktp., No. 5555.

Köprülü Ktp., Fâzil Ahmed Paşa, No. 355, 362.

Millet Ktp., Feyzullah Efendi, No. 474.

Nuruosmaniye Ktp., No. 695, 703.

Rabat, el-Hizânetü'l-âmme, No. 481.

Râgıb Paşa Ktp., No.335.

Süleymaniye Ktp., Ayasofya, No.773, 778.

Süleymaniye Ktp., Damat İbrahim, No. 267.

Süleymaniye Ktp., Denizli, No. 52.

Süleymaniye Ktp., Fatih, No. 1059.

Süleymaniye Ktp., Hacı Beşir Ağa, No. 161.

Süleymaniye Ktp., Hamidiye, No. 214.

Süleymaniye Ktp., Kılıç Ali Paşa, No. 263

Süleymaniye Ktp., Turhan Vâlide Sultan, No. 67.

Süleymaniye Ktp., Yazma Bağışlar, No Yazma Bağışlar. 1557.

Topkapı Sarayı Müzesi Ktp., III. Ahmed Kitaplığı, No. 250. 
Sahîh-i Buhârî Nüshalarına Dair Yeni Bulgular: Bulak Baskısı, Yûnînî Yazmaları ve Abdullah b. Sâlim el-Basrî Nüshası

Sahîh-i Buhârî̀nin Sultan II. Abdülhamid'in emriyle yapılan Bulak baskısında İstanbul'dan Mısır'a gönderilen ve baskıya esas kabul edilen yazma nüshanın Yûnînînin (ö. 701/1302) asıl nüshası olup olmadığı, bu mühim nüshanın basıldıktan sonraki âkıbeti, bu baskıda başka hangi yazmaların kullanıldığı ve Yûnînî nüshasının kopyaları hakkında, Yûnînîye dair çalışmaların azlığı ve kaynakların yetersizliği sebebiyle belirsizlikler mevcuttur. Bu belirsizlikleri gidermek amaciyla Türkiye’deki zengin yazma eser külliyatını kullanarak yaptığımız bu çalışmada Yûnînînin aslının Türkiye'de olmadığını, Ezher ulemâsı tarafından yapılan Bulak baskısında Yûnînînin en önemli kopyası kabul edilen Abdullah b. Sâlim el-Basrî (ö. 1134/1722) nüshasının esas alındığını, bunun yanında Muhammed el-Mizzî, Bedrânî ve Takıyyüddin es-Sübkî nüshaları ile Hâfız Yûsuf el-Mizzînin tashih ettiği Muhammed b. İlyâs nüshasının kullanıldığını tespit ettik. Türkiye'de bulunan Abdullah b. Sâlim nüshalarını ve Yûnînînin diğer kopyalarını tanıttık. Konuyla ilgili olarak Yûnînî öncesi ve sonrası benzer gayretlerin olduğunu ortaya koymak amacıyla İbn Hacer'in çok önemsediği Sagānî nüshasından ve İslâm âleminde Buhârînin ilk baskısını gerçekleştiren Sehârenpûrînin hâşiyesinden bahsettik. Bir kısmı araştırmacıların elinde olan ama ne olduğu farkedilemeyen, bir kısmı ise hiç bilinmeyen bu nüshaların ve bu makalede yer alan bazı bilgilerin yeni çalışmalara kapı aralamasını ümit ediyoruz.

Anahtar kelimeler: Buhârî, el-Câmiu's-sahîh, Yûnînî, Abdullah b. Sâlim el-Basrî, Sultan II. Abdülhamid, Bulak. 